Article

\title{
Characteristics of Point Recharge in Karst Aquifers
}

\section{Nara Somaratne}

South Australian Water Corporation, 250 Victoria Square, Adelaide, South Australia 5000, Australia; E-Mail: nara.somaratne@sawater.com.au; Tel.: +61-8-7424-2379; Fax: +61-8-7003-2379

Received: 3 July 2014; in revised form: 5 September 2014 / Accepted: 11 September 2014 /

Published: 23 September 2014

\begin{abstract}
Karstic groundwater basins are characterized by both point and diffuse recharge. This paper describes the hydrologic characteristics of point recharge and their influence on recharge estimation for four groundwater basins. Point recharge is highly transient and may occur in relatively short-time periods, yet is capable of recharging a large volume of water, even from a single extreme rainfall event. Preferential groundwater flows are observed in karst aquifers with local fresher water pockets of low salinity that develop around point recharge sources. Measurable fresh water plumes develop only when a large quantity of surface water enters the aquifer as a point recharge. In fresh water plumes, the difference in chloride concentrations in diffuse and point recharge zones decreases as the plumes become enriched through mixing. The relative contributions to total recharge from point sources using the measured gap between groundwater and rainwater chloride in the chloride $v s . \delta^{18} \mathrm{O}$ plot is not necessarily indicative of sinkholes not directly recharging the aquifer. In karst aquifers, recharge estimation methods based on groundwater age distribution; average annual rainfall and basin average chloride in the conventional chloride mass balance (CMB) method are questionable due to theoretical limitations and key assumptions of these methods not being met. In point recharge dominant groundwater basins, application of: watertable fluctuation, numerical groundwater modelling, Darcy flow calculation or water budget methods are more suitable for recharge estimation as they are independent of the particular mode of recharge. The duality of the recharge mechanism in karst aquifers suggests that modification to the $\mathrm{CMB}$ method may be required to include both point and diffuse recharge components.
\end{abstract}

Keywords: karst aquifers; resource assessment; point recharge; sinkholes; recharge in semi-arid; Australia 


\section{Introduction}

Groundwater resource assessment is germane to estimation of net recharge to the aquifers. A wide range of direct and indirect methods to estimate groundwater recharge, with varying degree of complexity and approximation on the range of spatial and temporal scales is available [1-4], but difficulties arise in complex karst hydrogeologic settings [5,6]. Recharge assessment is particularly challenging in semi-arid regions as recharge producing rainfall is highly irregular or episodic [7]. Aquifer water level response time may differ as the point and diffuse recharge residence times vary. Karst landscapes are often characterized by the presence of sinkholes, caves and underground conductive zones, formed primarily by dissolution of soluble limestone and dolomite. The presence of sinkholes gives a distinct recharge feature to karst systems via the duality of flow regimes, which can be separated into point (shaft and conduit dominated), and diffuse (matrix, meso-pore, and macro-pore dominated) infiltration and recharge.

Because of their high yields, carbonate aquifers are commonly used for community and non-community water supplies [8]. For example, $25 \%$ of drinking water supplies are sourced from a geological setting covering approximately $10 \%$ of the earth's land surface [9-11], and comprise some $40 \%$ of the groundwater of the United States [12]. In Europe, more than $30 \%$ of the land surface is made up of karst exposures with more than half the drinking water supply derived from karst aquifers in some countries [13]. Karst aquifers are poorly understood due to the spatial and temporal complexity of flow patterns caused by widely varying porosity and flow regimes [11].

A distinct recharge feature of karst systems is the duality of porosity, infiltration and recharge [5,6,14]. Karst limestone aquifers are hydrologically and hydrochemically extremely heterogeneous and point source recharge via sinkholes and fissures are common. In characterizing properties of a karst aquifer, quantitative water tracing tests utilizing fluorescent dyes, are among the most useful field methods [6]. Alternatively, naturally occurring tracers such as chloride and stable isotopic signatures of the water molecule $\left(\delta^{2} \mathrm{H}\right.$ and $\left.\delta^{18} \mathrm{O}\right)$ can be used to identify recharge and groundwater mixing, with either low salinity rainwater or surface water entering the aquifer via a point recharge source $[15,16]$. Herczeg et al. [16] suggest that the stable isotopic composition of waters recharging via sinkholes tends to be enriched in ${ }^{2} \mathrm{H}$ and ${ }^{18} \mathrm{O}$ relative to regional groundwater and local precipitation, due to the small degree of evaporation before recharge. Point-recharge is usually intermittent and transient. Discrete recharge to a karst aquifer, occurring through sinkholes, typically has numerous inputs of surface water to the subsurface, with water draining along cracks and fissures (macropores), rapidly transmitting water from the surface [17]. Hydrologic characteristics of karst aquifers are determined largely by the structures and organization of the conduits [18]. Rapid flow through point sources [19-22] is a common feature in highly heterogeneous and anisotropic [18,23] karst aquifers. Identification of groundwater flow paths in karst aquifers is therefore problematic [20].

One inherent problem from the presence of karstic features such as sinkholes is the recharge estimation. Whilst connected sinkholes transfer surface water to groundwater rapidly through shafts and conduits systems, unconnected sinkholes can act as regions of both rapid and slow recharge [24]. Sinkholes connected to the watertable bypass the soil zone, directly recharging the aquifer as point recharge. Unconnected sinkholes add runoff deeper into the unsaturated zone, which can then rapidly drain into the watertable via macropores and slow infiltration through the soil profile between the 
sinkhole bottom and watertable plane [14,24]. Karstic features supply a significant amount of recharge to many carbonate aquifers in temperate and humid regions throughout the world [16], yet the applicability of the assumptions used in recharge estimation methods has not been studied. For example, the fundamental basis of the conventional $\mathrm{CMB}$ method is that recharge mass flux crossing the watertable plane can be calculated if the following conditions are met [25-27]:

- chloride in the groundwater originates from precipitation directly on the aquifer, and no unmeasured runoff occurs;

- there is steady influx of water and chloride; and

- chloride is conservative in the system and there are no other sources or sink in the aquifer,

Problems arise holding above assumptions, which rely on steady chloride mass flux crossing the watertable plane and long-term average annual rainfall. Under point recharge situations, it appears that the basic premise of the conventional CMB method is violated.

This study addresses karst systems, with particular reference to the chloride $v s \delta^{18} \mathrm{O}$ relation, groundwater mixing, preferential flowpaths and water level response of karst aquifers to episodic and annual rainfalls, with respect to the validity of assumptions of the commonly used recharge estimation method, the conventional CMB.

\section{Description of the Study Basins}

Four groundwater basins, based on data availability and differing rainfall zones, in karstic settings in South Australia (Figure 1) are examined.

Figure 1. Location of study basins.

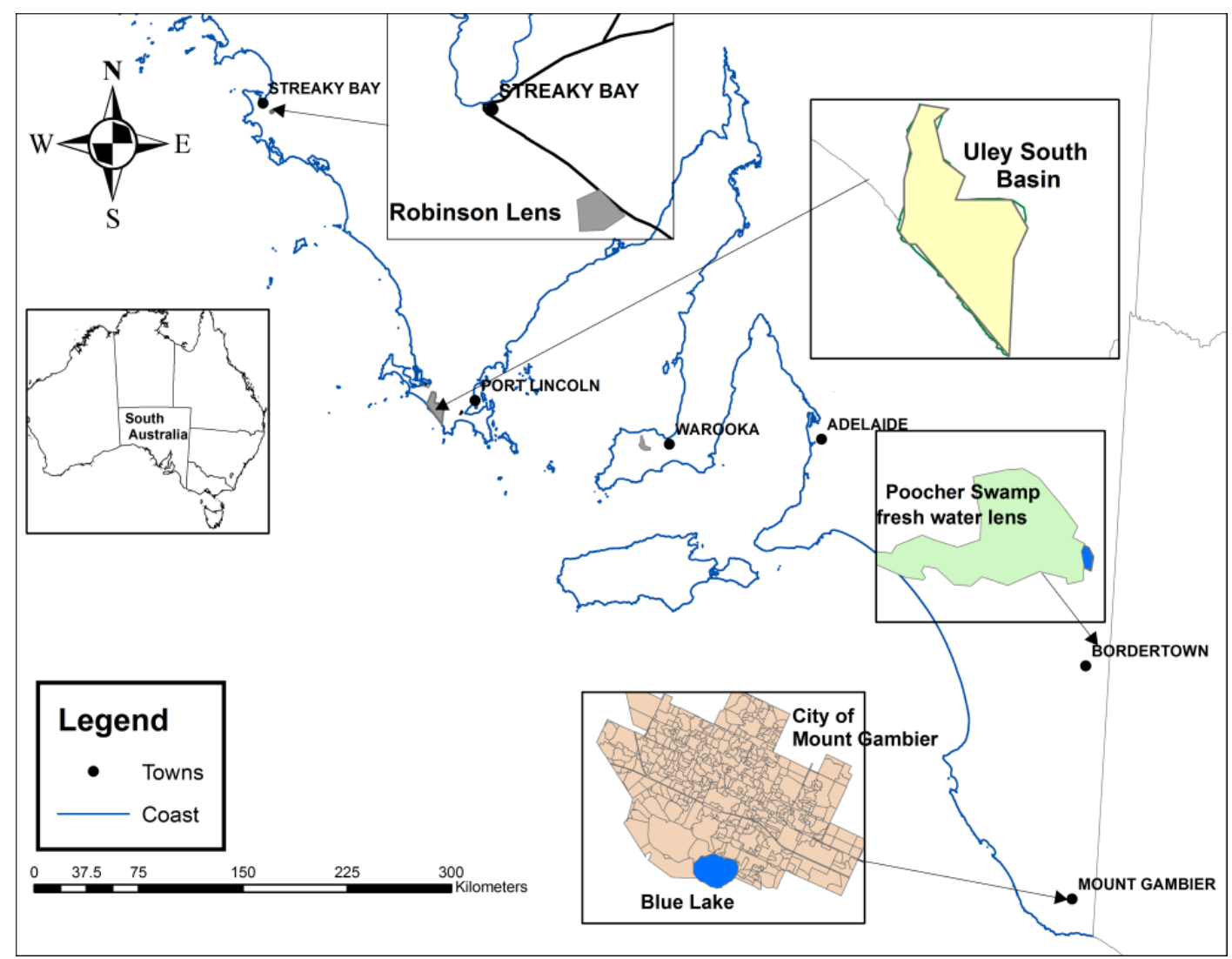


The basins are characterized by both point and diffuse recharge. In the Robinson lens and Uley South basin, point recharge is through solution features and diffuses recharge through granular porosity of pockets of soil and minor fissures and cracks. In the city of Mount Gambier within the Blue Lake capture zone, point recharge is mainly through about 400 storm water drainage wells and three sinkholes [28]. In Poocher Swamp, the majority of recharge is from a large volume of creek water discharge into two sinkholes, resulting in formation of a fresh water lens [29]. Groundwater basins Uley South [30,31], Robinson lens [31], and Blue Lake capture zone in Mount Gambier [28] are previously described and therefore essential hydrogeogical features of the basins are provided below.

Robinson lens is a small fresh groundwater lens $\left(4.7 \mathrm{~km}^{2}\right)$ located on the western Eyre Peninsula, $8 \mathrm{~km}$ south-east of the township of Streaky Bay (Figure 1). This basin has provided reticulated water supply to the township for more than 70 years. Average annual rainfalls is $375 \mathrm{~mm}$ and mean annual pan evaporation is $2200 \mathrm{~mm}$. Falling water levels and rising groundwater salinity have been observed indicating that extraction from the lens exceeds recharge (Figure 2). Groundwater extraction from the basin ceased in 2005, and since then, recovery of approximately $60 \%$ has been observed as of January 2014. The basin area is overlain by unconsolidated calcareous sand and calcarenite of the Bridgewater Formation [32], which is capped by calcrete. Immediately underlying the Bridgewater Formation are stiff plastic Tertiary clays of the Wanilla Formation. Beneath this sequence are unnamed brackish to saline Jurassic sands and silts. Significant karst development in the form of dissolution features are common, and are evident on the calcrete exposures in the lower topographic depressions. The origin of the fresh water lens is attributed to runoff flowing to the low-lying parts of the lens where karst topography allows recharge to occur very quickly via 29 major solution features spread across the lens. Depth to water is 4 to $20 \mathrm{~m}$ suggesting that the watertable is not directly influenced by evaporation [32].

Figure 2. Conceptual diagram of the Robinson lens.
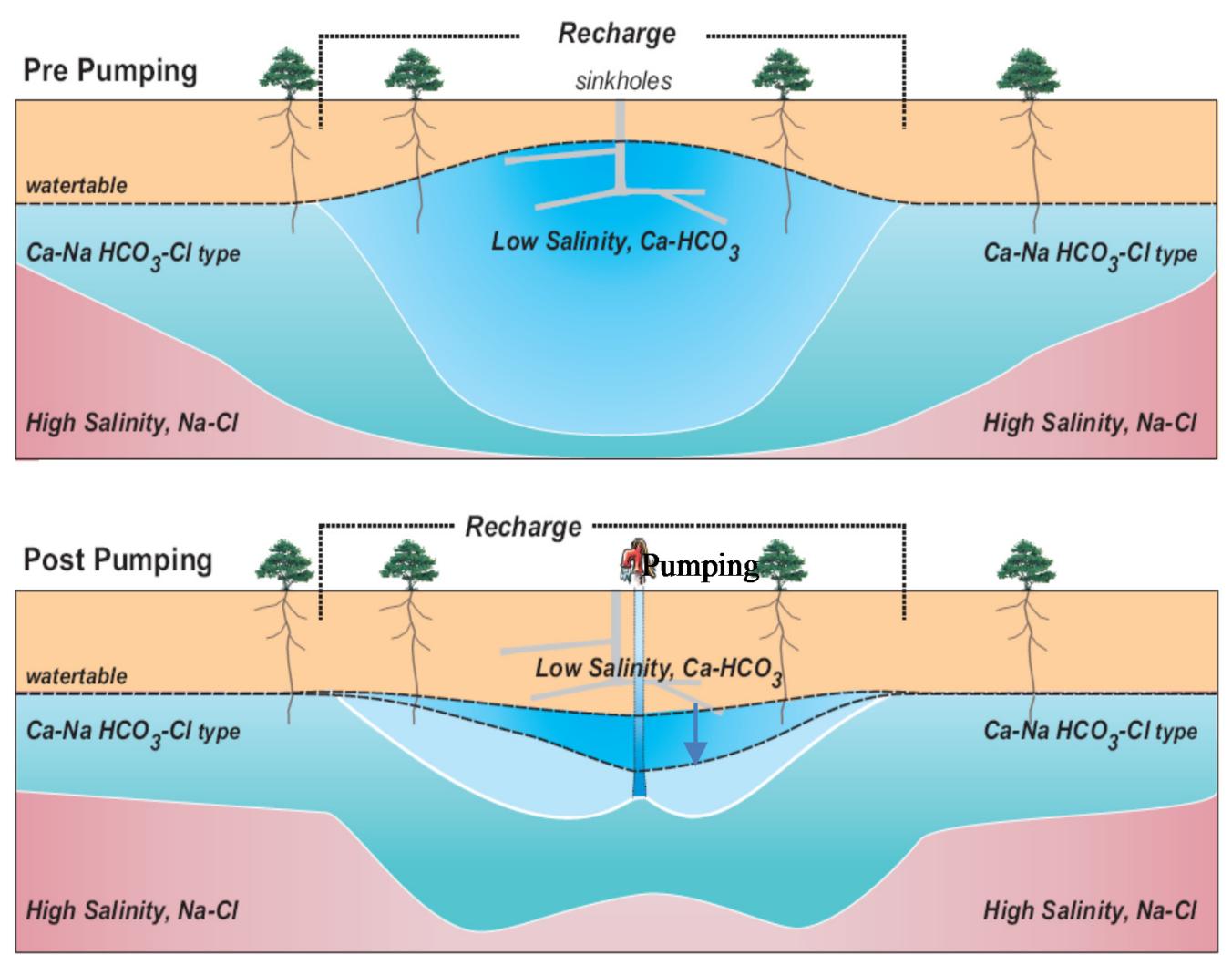
The second study site is the Uley South basin; approximately $113 \mathrm{~km}^{2}$ in area is located on the Southern Eyre Peninsula of South Australia (Figure 1). Average annual rainfall is $550 \mathrm{~mm}$ and average annual pan evaporation is $1550 \mathrm{~mm}$. The basin has been used for reticulated town water supply since 1976 and currently about $6.8 \times 10^{6} \mathrm{~m}^{3}$ per year of groundwater is extracted from the Quaternary limestone aquifer. The surface geology of the Uley South basin is Quaternary sediments of Bridgewater Formation unconformably overlying Proterozoic volcano-sedimentary basement sequence [33]. The hydrogeology of Uley South basin comprises Quaternary limestone of an average thickness of $15 \mathrm{~m}$, followed by a Tertiary clay unit of 5-25 m thickness, and a Tertiary sand aquifer (Figures 3 and 4). The Tertiary clay forms an aquitard between the Tertiary sand and the Quaternary aquifer systems. Groundwater flow direction is from north-east to south-west. The basin is topographically closed and bounded by coastline and sand dunes to the west and inland to the north and east by topographic rises of dry limestone (allogenic zone), except along the north-eastern edge. The low lying central part of the basin contains numerous sinkholes (autogenic zone). Runoff is highly ephemeral, occurring only after moderate to high intensity rainfall and persisting only tens to hundreds of meters before entering a sinkhole [33-35]. A survey of a $4 \mathrm{~km}^{2}$ area found a density of about one sinkhole per $0.07 \mathrm{~km}^{2}$ with approximate size ranging from $0.4 \mathrm{~m}$ to $2.5 \mathrm{~m}$ diameter [36].

Figure 3. Sinkholes in Uley South basin (a) Surveyed sinkholes (b) View of a sinkhole in a natural depression.

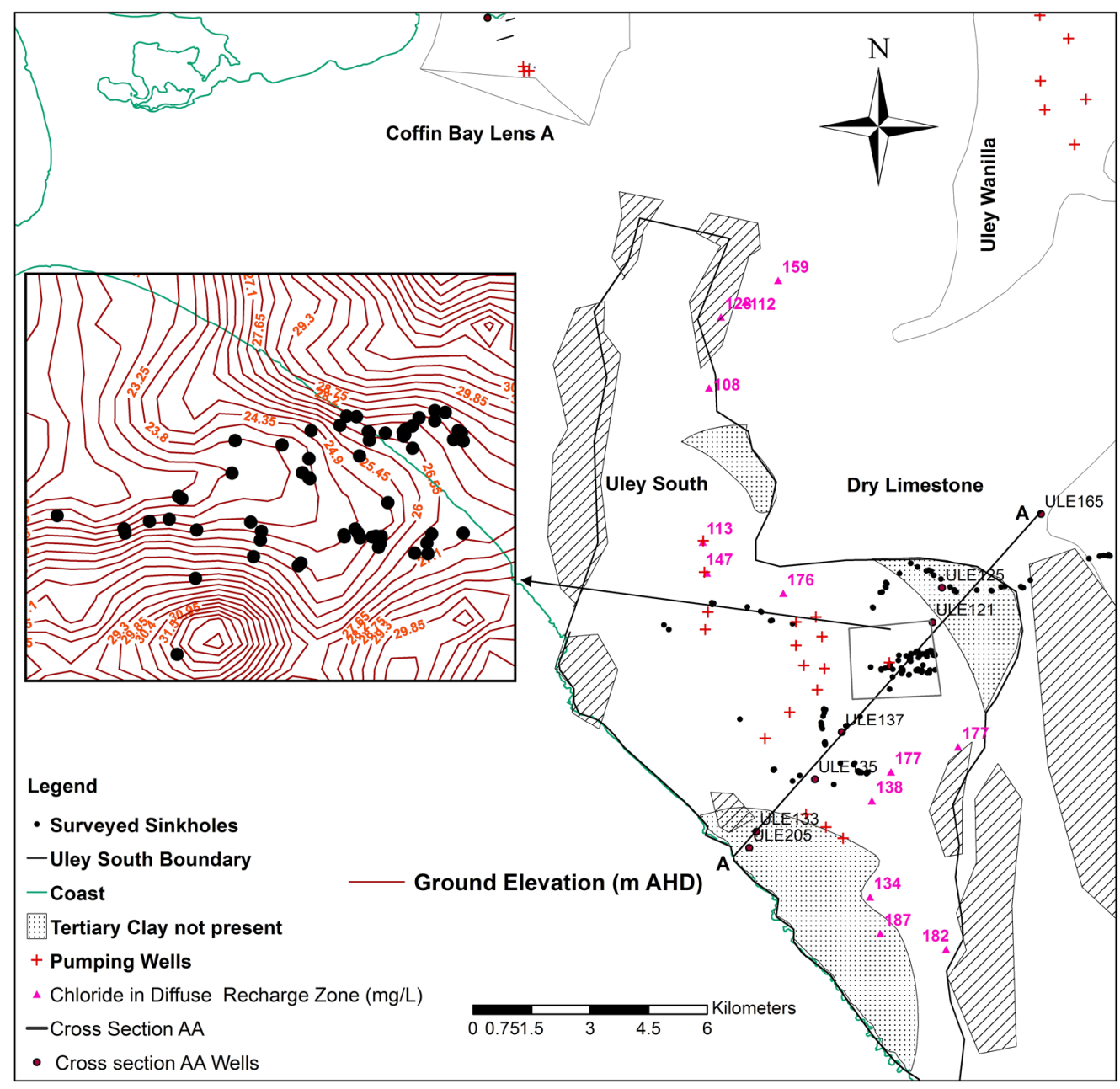

(a) 
Figure 3. Cont.

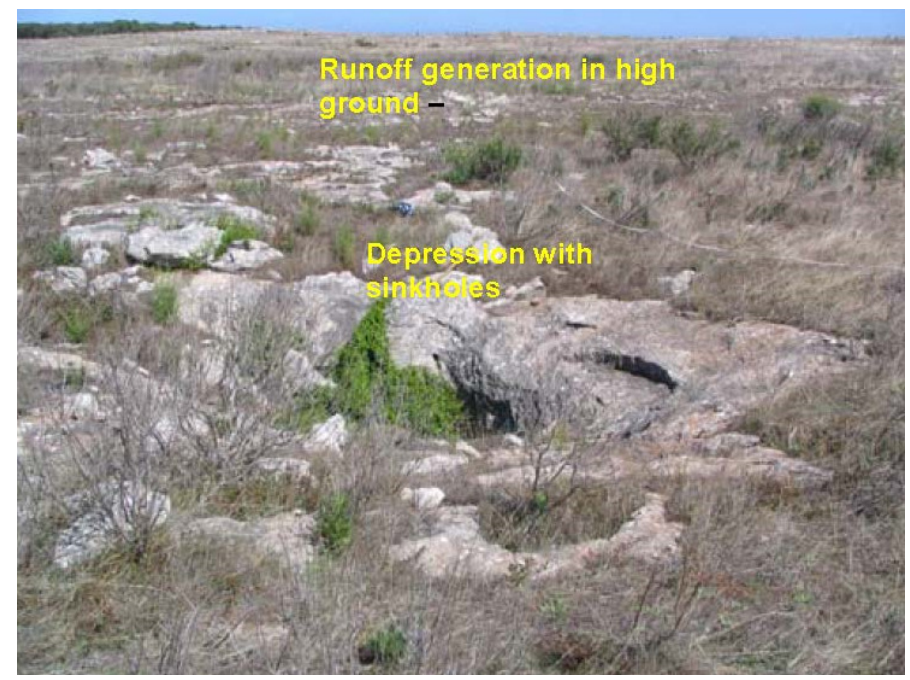

(b)

Figure 4. Cross section AA-Uley South basin [30].

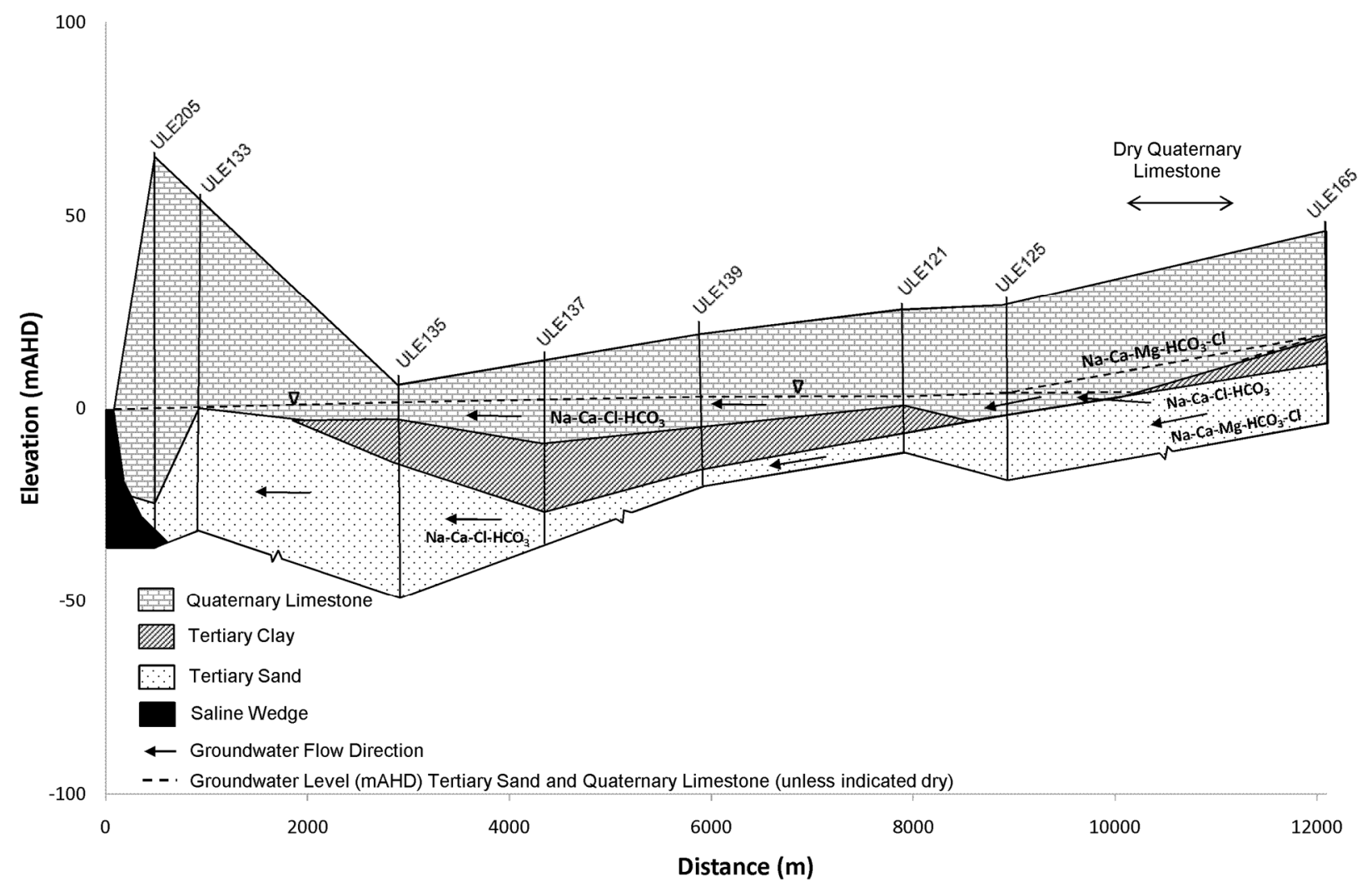

The third study area is the Blue Lake capture zone in the city of Mount Gambier. Blue Lake is a volcanic crater complex, and is the water supply reservoir for the city [37] located in the south-east of South Australia (Figure 1). The lake is groundwater fed through an extensive karst aquifer [38,39]. Currently $3.6 \times 10^{6} \mathrm{~m}^{3}$ is extracted annually for town water supply. The main source of recharge to the Blue Lake is groundwater from the unconfined, Gambier karstic limestone aquifer underlying the urban area. Average saturated thickness of the Gambier limestone aquifer is about $60 \mathrm{~m}$. Storm water 
derived from the central $16.8 \mathrm{~km}^{2}$ of the city area $\left(26.5 \mathrm{~km}^{2}\right)$ is discharged to the unconfined aquifer through three sinkholes and about 400 storm water drainage wells [40].

The Blue lake capture zone is located about $20 \mathrm{~km}$ from the coastline. Average annual rainfall in Mount Gambier is $750 \mathrm{~mm}$ and average annual pan evaporation is $1400 \mathrm{~mm}$. Regional groundwater flow direction is from north to south; however, Blue Lake receives groundwater flow from the north-west to north-east direction of the capture zone [41]. The study area is located within the Blue Lake capture zone of the Gambier Basin (Figure 5), a mixed sequence of marine and terrestrial deposits [42].

Figure 5. Mount Gambier city area of the Blue Lake capture zone.

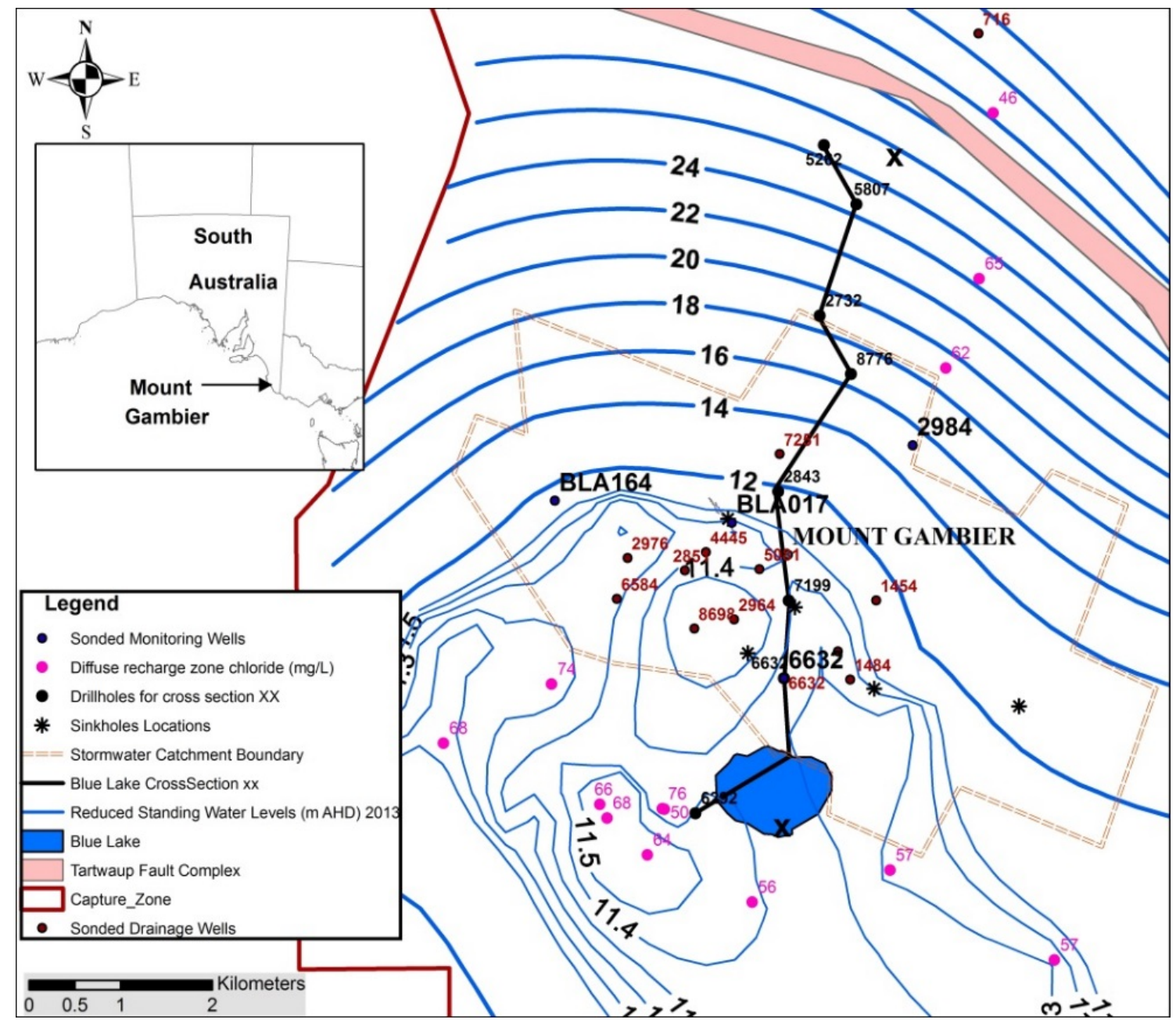

The main geological units in the Mount Gambier area, in downward order, consist of Holocene volcanic deposits, the Bridgewater Formation (stranded Pleistocene beach dunes), the Gambier Limestone and the Dilwyn Formation [43]. The unconfined aquifer within the Gambier Limestone is a continuous system and an important supplier of groundwater throughout the region. Karstic features are common within the Gambier Limestone. Underlying the Gambier Limestone is the Dilwyn Formation, which comprises a series of unconsolidated sands with carbonaceous clay interbeds (Figure 6). The Dilwyn Formation hosts a confined aquifer with higher salinity than the Gambier Limestone. A major fault underlies the Blue Lake, which is thought to represent a zone of regional structural weakness through which volcanic activity has occurred. 
Figure 6. North-south cross section across the city-XX in Figure 5 [28].

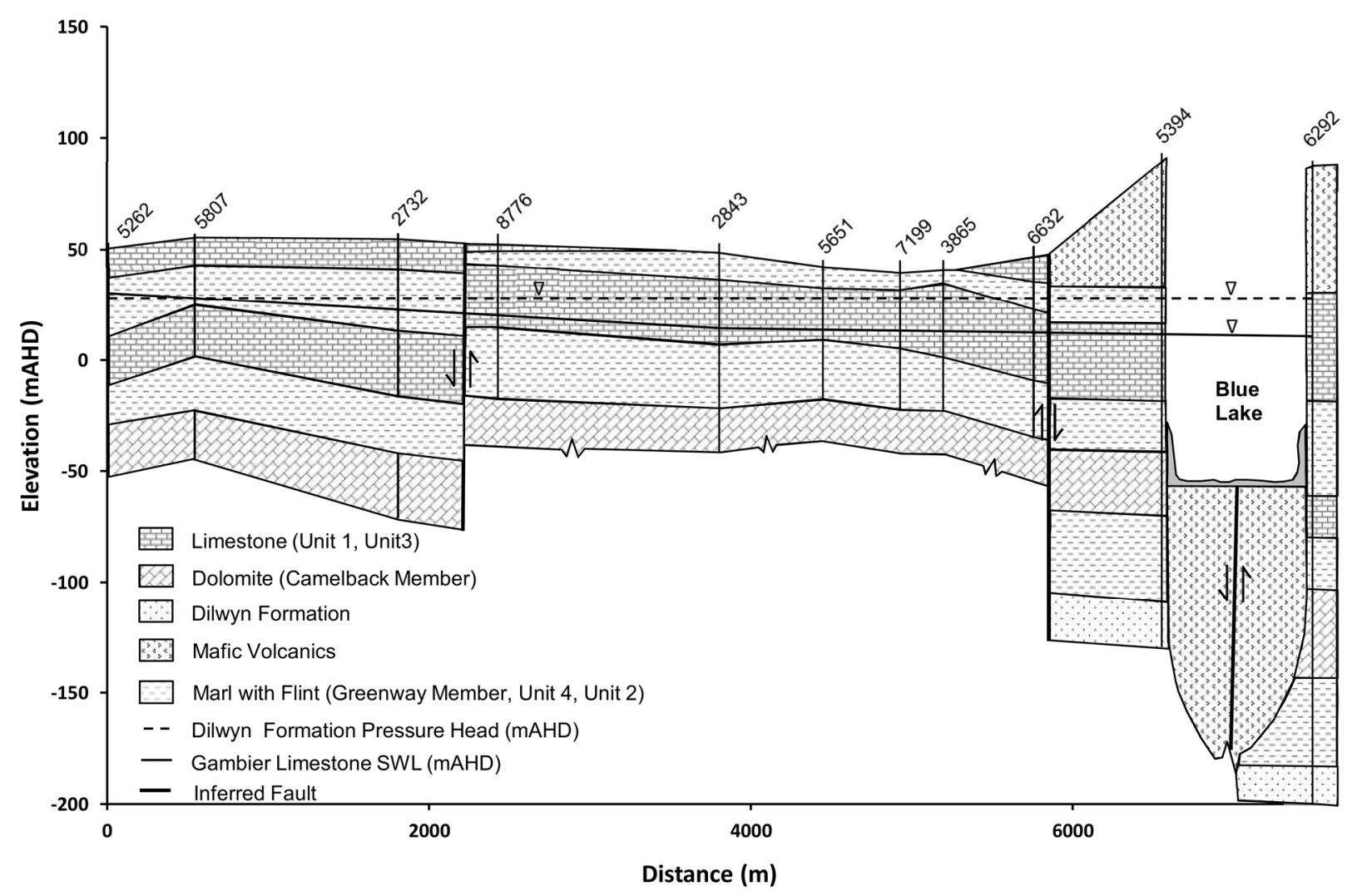

Recently, Lawson [41] refined the stratigraphy of the Gambier Limestone surrounding the Blue Lake, defining the subunits within the Gambier Limestone in hydrostratigraphic terms (Figure 6). The following are general descriptions of the unconfined aquifer hydrostratigraphic unit characteristics as described by Lawson [41] and Li et al. [44]. Green Point Member Unit 1 (Unit 1) is a transmissive bryozoal limestone with marl and flint inclusions. Green Point Member Unit 2 (Unit 2) is composed of marls and flints, has the potential to act as a semi-confining unit and is characterised by generally lower transmissivities with associated low hydraulic conductivity. Green Point Member Unit 3 (Unit 3) is described as an open transmissive bryozoal limestone. It contains minor fracturing and may be partly dolomitised. This unit is characterised by higher aquifer transmissivities and associated hydraulic conductivity. Green Point Member Unit 4 (Unit 4) is typically described as a deep marl section within the limestone. It may act as an aquitard with typically associated lower hydraulic conductivity. Camelback Member is a dual porosity unit, characterised by extensive fracturing at the subunit intersection point. This results in extremely high porosities and hydraulic conductivities. The non-fractured sections of the subunit are composed of fine dolomitic rhombs and have transmissivities probably similar to or lower than bryozoal sections of limestone. Greenways Member is typically described as grey basal marl with resultant low transmissivities and hydraulic conductivity [28].

The fourth study site is located in the Tatiara catchment, which extends across the South Australian border into Western Victoria, and features average annual rainfall ranging from 400 to $500 \mathrm{~mm}$ and pan evaporation of $2000 \mathrm{~mm}$. The catchment area is approximately $500 \mathrm{~km}^{2}$ [16]. The unconfined aquifer is Murray Group Limestone and contains brackish water with average TDS (total dissolved solids) $>1400 \mathrm{mg} \cdot \mathrm{L}^{-1}$, with a chloride concentration of $>500 \mathrm{mg} \cdot \mathrm{L}^{-1}$ [45] (Figure 7). 
Saturated thickness of the limestone unconfined aquifer is approximately 50-60 m (Figure 8). Fresh water with TDS $<1000 \mathrm{mg} \cdot \mathrm{L}^{-1}$ occurs at locations where point recharge takes place through sinkholes. Poocher Swamp's fresh water lens, which is the largest of these fresh water plumes that float on brackish water, is a result of flows from Tatiara Creek that enter Poocher Swamp (Figure 7). The major recharge is through two sinkholes located in the north-west section of the swamp [16]. The area encompassed by the $1000 \mathrm{mg} \cdot \mathrm{L}^{-1}$ salinity contour comprises approximately $20 \mathrm{~km}^{2}$. This catchment generates irregular annual volumes of freshwater $0.05 \times 10^{6}-2 \times 10^{6} \mathrm{~m}^{3}$ per year, but on rare occasion up to $19 \times 10^{6} \mathrm{~m}^{3}$ per year. Poocher Swamp is located some $200 \mathrm{~km}$ north of Mount Gambier. Groundwater flow direction is from east to west. Currently, an annual volume of $0.6 \times 10^{6} \mathrm{~m}^{3}$ of groundwater is extracted from the fresh water lens for town water supply with average salinity $490 \mathrm{mg} \cdot \mathrm{L}^{-1}$ and chloride concentration of $115 \mathrm{mg} \cdot \mathrm{L}^{-1}$.

Figure 7. Poocher Swamp fresh water lens.

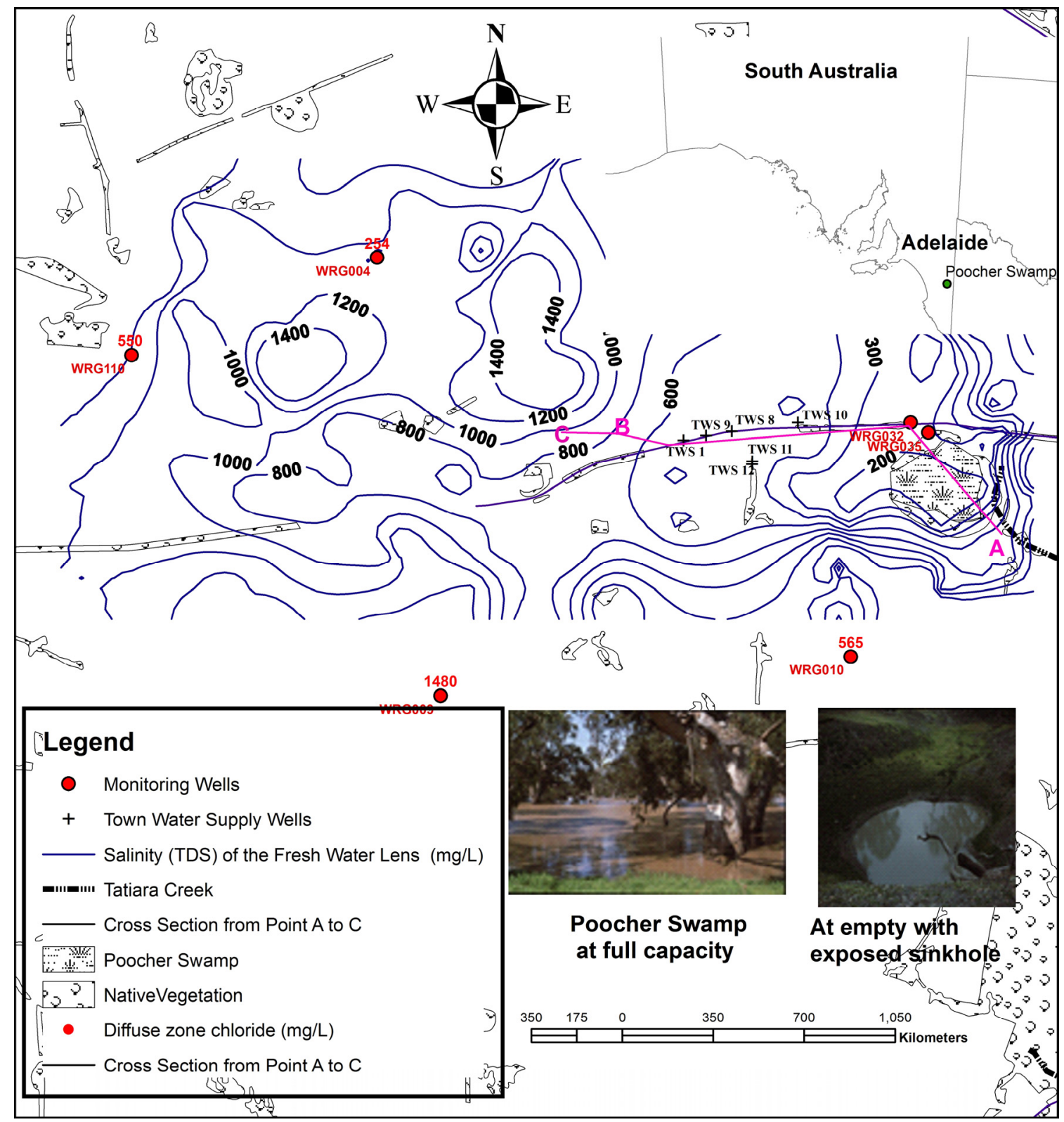


Figure 8. Cross section from point A to $\mathrm{C}$ in Figure 7-Poocher Swamp fresh water lens.

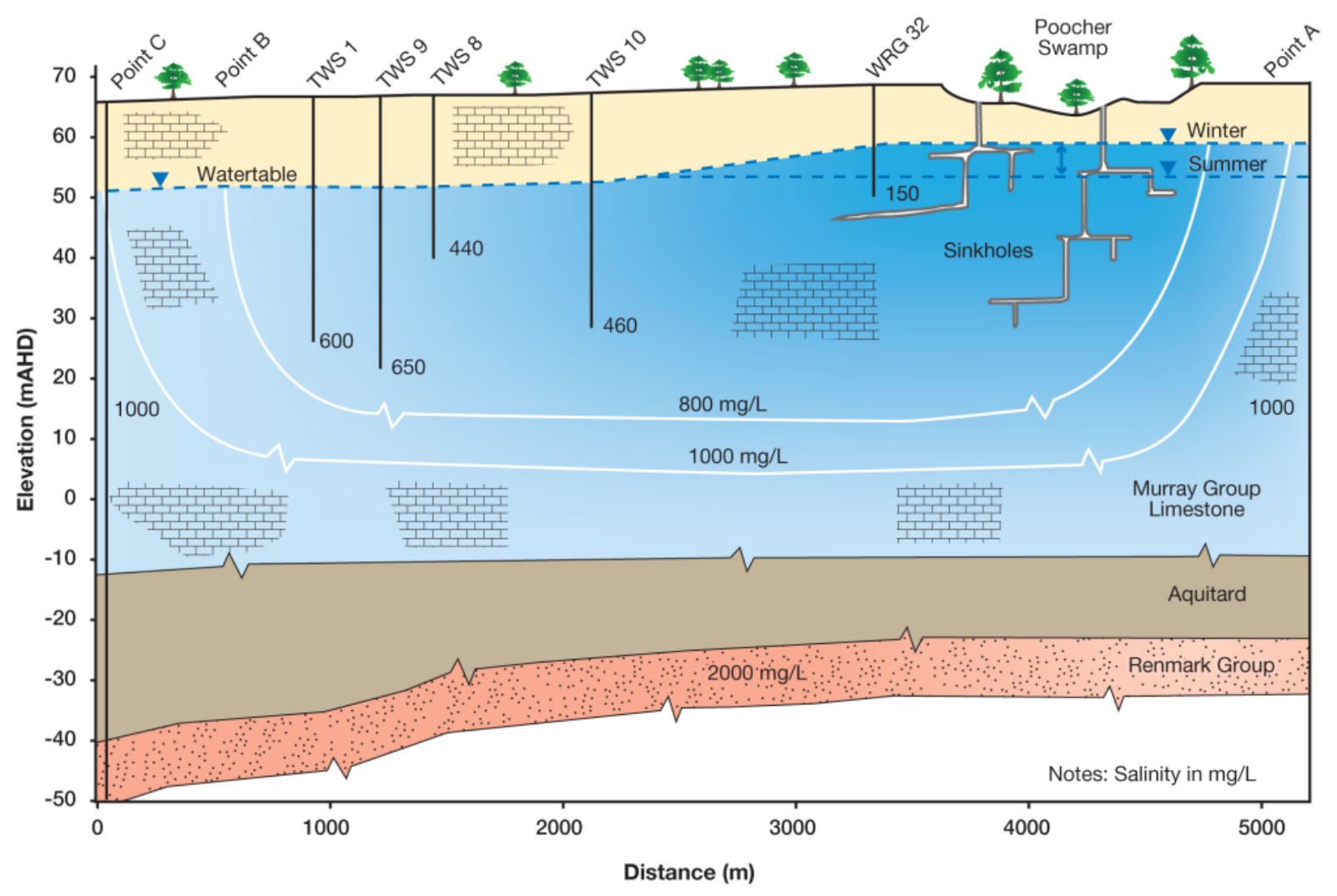

\section{Methods}

\subsection{Field Measurements and Laboratory Analysis}

Groundwater chloride and stable isotope $\left(\delta^{2} \mathrm{H}\right.$ and $\left.\delta^{18} \mathrm{O}\right)$ for the Uley South basin is from Evans [33], with further groundwater samples collected in 2008. Data gaps were filled by linear regression of TDS to chloride $\left(R^{2}=0.98\right)$ for monitoring wells where TDS are available but no chloride measurements have been undertaken. Selected monitoring wells are away from brackish water upward leakage areas and salinity stratified wells [30], the swamp and coastal monitoring wells to avoid chloride contamination from other sources. For the Blue Lake capture zone, existing groundwater chloride data were supplemented with samples taken from unconfined aquifer monitoring wells within and outside the city [28]. Selected sampling wells are away from historically known contaminated sites. In addition to the monitoring wells, groundwater samples were taken from drainage wells and surface runoff for major ion and stable isotope analyses. Salinity profiles taken by sonding in 2011 and 2012 for selected monitoring and drainage wells were used to study vertical distribution. Water samples were collected from Tatiara Creek, Poocher Swamp, aquifer monitoring wells and town water supply wells in 2012 and 2014. For Robinson lens, chloride and stable isotope data are from Brown and Harrington [32].

Additional groundwater samples for major ion and stable isotope analysis were collected using micro-purge (low-flow) sampling procedure [46] and grab sampling technique. The micro sampling is employed to gain representative groundwater samples within open hole of monitoring and drainage wells. Low-flow purging is considered [46] superior to bailing and high-rate pumping and results in a more representative sample than the typical well purge methodology. The assumption in the grab 
sampling is that the hydrostratigraphy in the well is in hydraulic equilibrium prior to sampling [28]. To collect the sample by this method, an electronic depth sampler connected to a geophysical logging line is advanced to the target sampling depth and the unit is electronically opened, allowing groundwater to enter the sampler. Water samples were preserved according to the standard methods specified in AS/NZS 5667.5 [47] guidelines. Samples were analysed for major ion chemistry at the Australian Water Quality Centre (AWQC) in Adelaide. The analysis of $\mathrm{Ca}, \mathrm{Mg}, \mathrm{Na}, \mathrm{K}, \mathrm{SO}_{4}$ is based on Method 3120B-Metals by Plasma Emission Spectroscopy [48]; for the analysis of chloride, Method 4500-Cl Chloride-E (Automated Ferricyanide Method) [49] and for the analysis of $\mathrm{HCO}_{3}$ Method 2320 Alkalinity-B [50] was followed using Radiometer Autotitrator. Water samples for stable isotope analysis were collected in $30 \mathrm{~mL}$ McArtney glass bottles with metal screw top lids with rubber insert. In order to reduce evaporation, samples were stored and transported inverted. Stable isotope $\left(\delta^{2} \mathrm{H}\right.$ and $\delta^{18} \mathrm{O}$ ) samples were analysed at the CSIRO isotope laboratory in Adelaide. The standard procedure for analysis of the Oxygen-18 composition of water is that described by Epstein and Mayeda [51] with CSIRO isotope laboratory modification involving equilibration of $\mathrm{CO}_{2}$ with $1 \mathrm{~mL}$ of water in a temperature controlled block held at $50{ }^{\circ} \mathrm{C}$ for $8 \mathrm{~h}$. The preparation and extraction of the $\mathrm{CO}_{2}$ is automated using 59 port water equilibration system (WES). This is attached to a GEO 20-20 dual inlet stable isotope gas ratio mass-spectrometer [52]. The WES method is also used for analysis of the Deuterium composition of water. The method is similar to ${ }^{18} \mathrm{O}$ analysis via WES except that, for ${ }^{2} \mathrm{H}$ analysis, hydrogen atoms from the water molecules are equilibrated with hydrogen gas rather than oxygen atoms equilibrating with oxygen in $\mathrm{CO}_{2}$.

Salinity profiles of monitoring and drainage wells were obtained using Hydrolab 600XLM Sonde [53] connected to a laptop computer. The sonde was calibrated using conductivity standard placed in a pre-rinsed and dry calibration cup, with the probe end of the sonde immersed into the solution and calibrated according to the procedure in the manual. The sonde was connected to a $120 \mathrm{~m}$ length cable and lowered down the well from surface to the well base, recording electrical conductivity (EC) data along the way. The calibrated 600 XLM Sonde has a conductivity range of $0-100,000 \mu \mathrm{S} / \mathrm{cm}$ with accuracy of measurements $\pm 0.5 \%$ reading $+1 \mu \mathrm{S} / \mathrm{cm}$, and can operate in a temperature range $-5{ }^{\circ} \mathrm{C}$ to $45^{\circ} \mathrm{C}$ up to $200 \mathrm{~m}$ depth.

\subsection{Method of Data Analysis}

Characteristics of point recharge were assessed using chloride $v s \delta^{18} \mathrm{O}$ relation, and groundwater mixing. Enrichment of stable isotopes, $\delta^{2} \mathrm{H}$ and $\delta^{18} \mathrm{O}$ and conservative tracers such as chloride, is used as an indicator of water loss by evaporation and transpiration [54,55]. This was assessed by plotting chloride $v s . \delta^{18} \mathrm{O}$ to identify chloride enrichment at or near point recharge sources. With regards to groundwater mixing in Poocher Swamp fresh water lens, groundwater was classified into "water types" on the basis of the absolute and relative abundance of major ions [56]. The Piper diagram is commonly used to graphically displaying the bulk chemical composition of groundwaters, and it was therefore used to identify groundwater mixing and classification into water types. Karst aquifer response to extreme rain event was studied for Robinson lens, Streaky Bay. Aquifer monitoring data obtained two weeks after an extreme rain event, are presented in the form of water level contour maps and time series of water levels. Long-term basin water level responses to annual recharge was estimated for the 
karst limestone aquifer of Uley South, and diffuse recharge aquifer of adjacent Coffin Bay fresh water lens. These data are presented in the form of a regression analysis.

\section{Results and Discussion}

\subsection{Aquifer Water Level Response to Extreme Rainfall Event and Annual Rainfalls in Karst Aquifers}

The basic controls on diffuse recharge include climate, vegetation, soils, and topography [57]. In many settings, diffuse recharge through the soil profile is a relatively slow process. The recharge flux reaching the watertable plane is enriched in salinity and other constituents as a result of evapotranspiration. In contrast, point recharge via sinkholes that are directly connected to the watertable plane is usually of surface water quality, as these fluxes escape evapotranspiration. For shallower water tables, a linear relationship between depth to the water table and water-level response time is evident in granular porosity aquifers [58]. Typically, connected sinkholes add large volumes of water to the aquifer in a relatively short time, while conduit systems in the aquifer may rapidly transport and remove it leading to short residence time [24].

This is evident in recent water level responses to an extreme rain event in the Robinson lens, where $109 \mathrm{~mm}$ of rainfall was received on 14 February 2014. After allowing a period of two weeks for stability, on 28 February, water levels were monitored in the lens and show on average $0.45 \mathrm{~m}$ water level rise, a threefold increase on the long-term average annual watertable rise (Figure 9). A comparison of water level recovery in the lens is shown in Figure 10. In 1979, groundwater levels ranging from $0.3 \mathrm{~m}$ to $0.7 \mathrm{~m}$ above sea level of the original groundwater mound existed within the lens (Figure 10a) and this was depleted to $1.8 \mathrm{~m}$ below sea level in 2005. Following a period of no pumping from April 2006-January 2014 water levels recovered by $1.1 \mathrm{~m}$ at the lowest point, near pumping well "Bore 20" (Figure 10b). As a result of the extreme rainfall event on 14 February 2014, the water level further recovered by $0.45 \mathrm{~m}$ at the lowest point (Figure $10 \mathrm{c}$ ).

Figure 9. Reduced Standing Water Level (RSWL) fluctuations in the Robinson lens (a) selected hydrographs with inset from March 2013 to May 2015 (b) Air escaping through a fissure in calcrete (macropore) during rapid recharge.

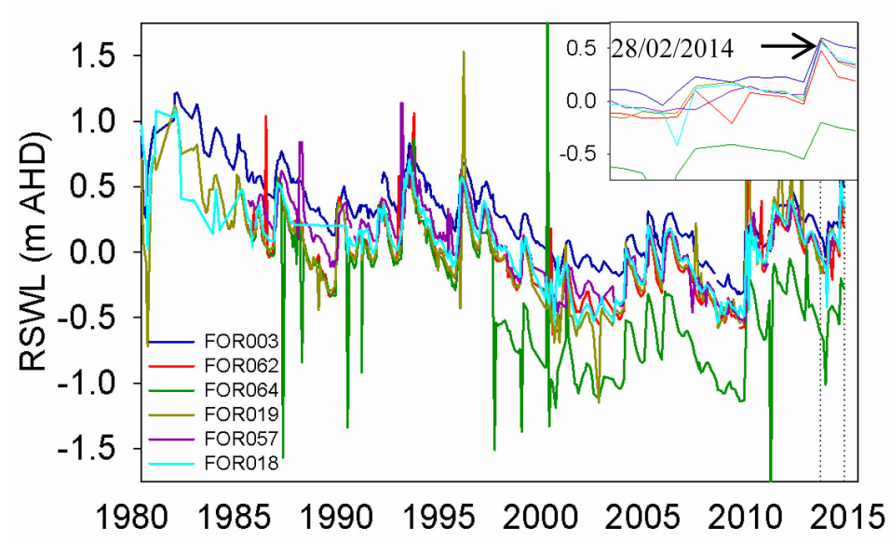

(a)

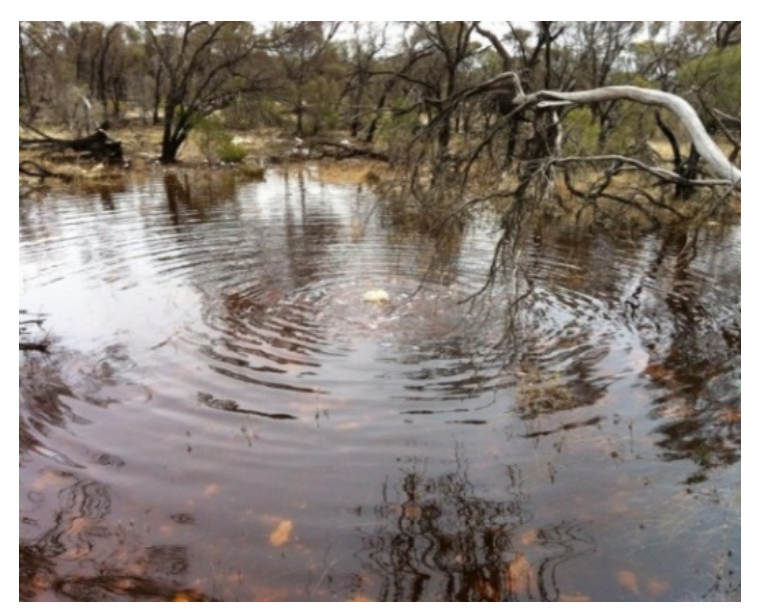

(b) 
Figure 10. Water levels in Robinson lens (a) September 1979 (b) January 2014 (c) 28 February 2014.

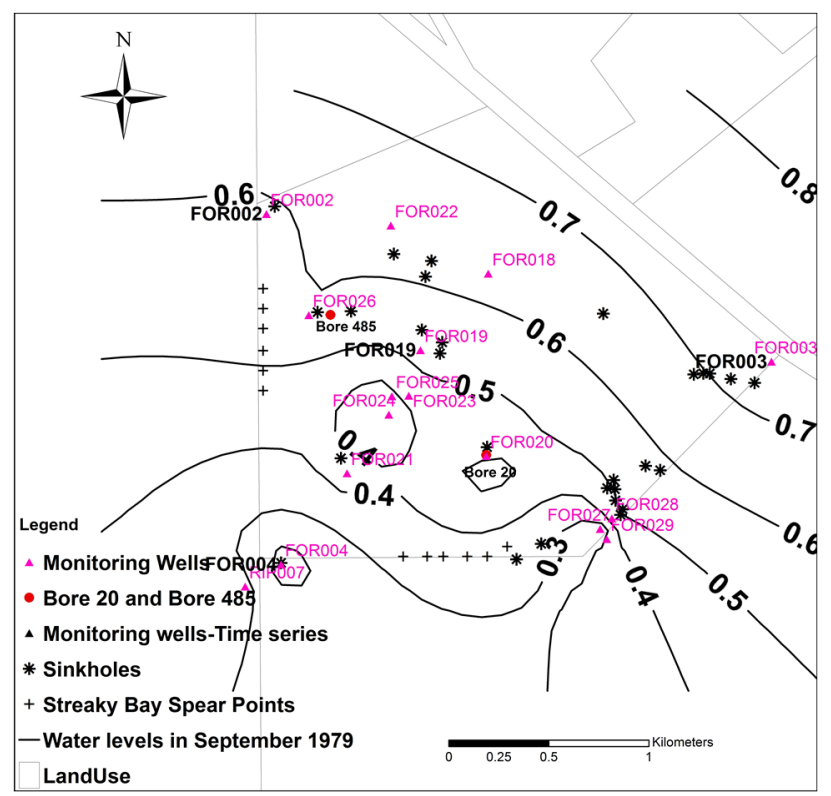

(a)

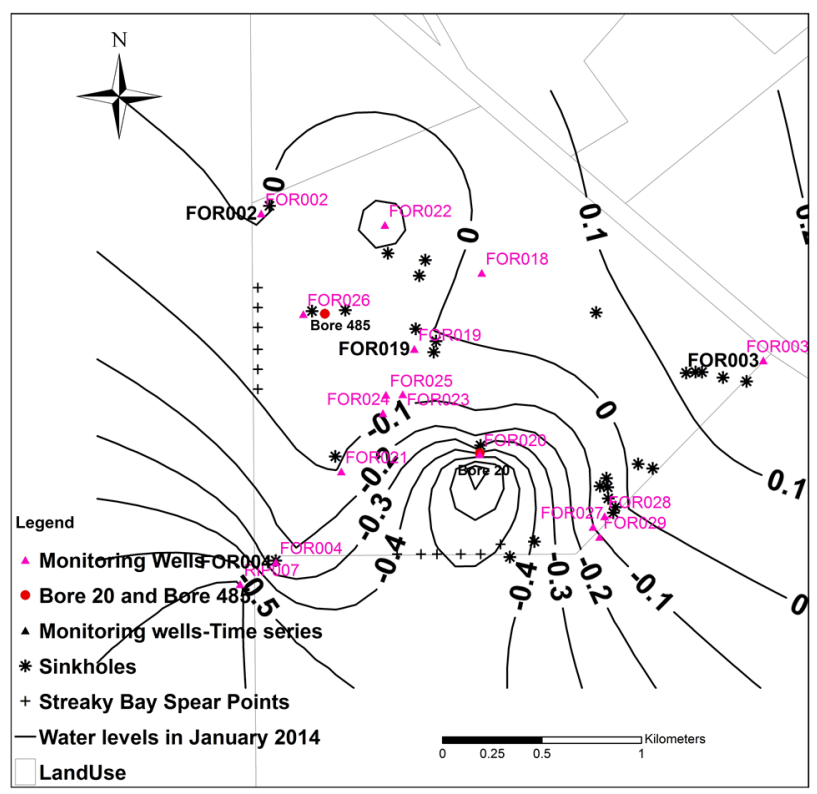

(b)

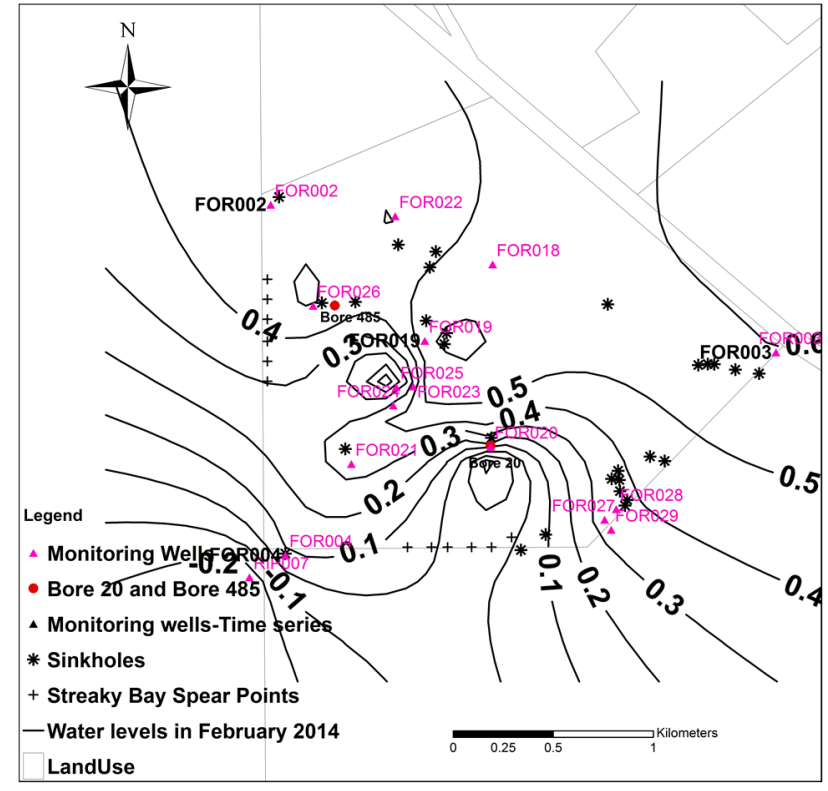

(c)

Water level response to annual rainfall is compared in the Uley South basin, a karst aquifer, with the adjacent Coffin Bay lens A, a diffuse recharge aquifer [31]. Both aquifers adjoin the coast. Depth to water is shallower (3-20 m) in Coffin Bay lens A than Uley South, which is $8-20 \mathrm{~m}$ in most locations and greater than $20 \mathrm{~m}$ under sand dunes and basin boundaries. Vegetation is sparse in both basins, except on sand dunes. Recharge in Uley South is through karst features (Figure 3) such as epikarst and sinkholes; and diffuse infiltration and recharge is through pockets of soil that occur in the basin, through the base of the unconnected sinkholes, and at locations where sinkholes have collapsed and filled with sediments. In contrast recharge in Coffin Bay lens A, is by infiltration through sandy surface soil and underlying calcarinite. 
A comparison of average basin water level rise during recharge periods (from April/May to September/October), to annual rainfall is presented for Uley South and Coffin Bay lens A in Figure 11. Data records from 1960 to 2010 for Uley South, and from 1985 to 2010 for Coffin Bay lens A were used. Rainfall is measured at Big Swamp station, located $18 \mathrm{~km}$ east of Coffin Bay, and north-east from Uley South. In both basins, the spatial average of water level response to long-term average annual rainfall $(550 \mathrm{~mm})$ is similar, $0.22 \mathrm{~m}$ for Uley South and $0.2 \mathrm{~m}$ for Coffin Bay lens A. As the annual rainfall increases, the corresponding water level increases rapidly in Uley South. For example, the highest rainfall $(917 \mathrm{~mm})$ in the last century occurred in 1968, resulting in $1 \mathrm{~m}$ water level rise in the basin. Even though the second highest recorded rainfall $(873 \mathrm{~mm})$ occurred in 1992, the water level rise is lower than under the predevelopment conditions in 1964 (669 mm).

Figure 11. Basin water level response to annual rainfall in Uley South basin and Coffin Bay lens A. (a) Uley South; (b) Coffin Bay.

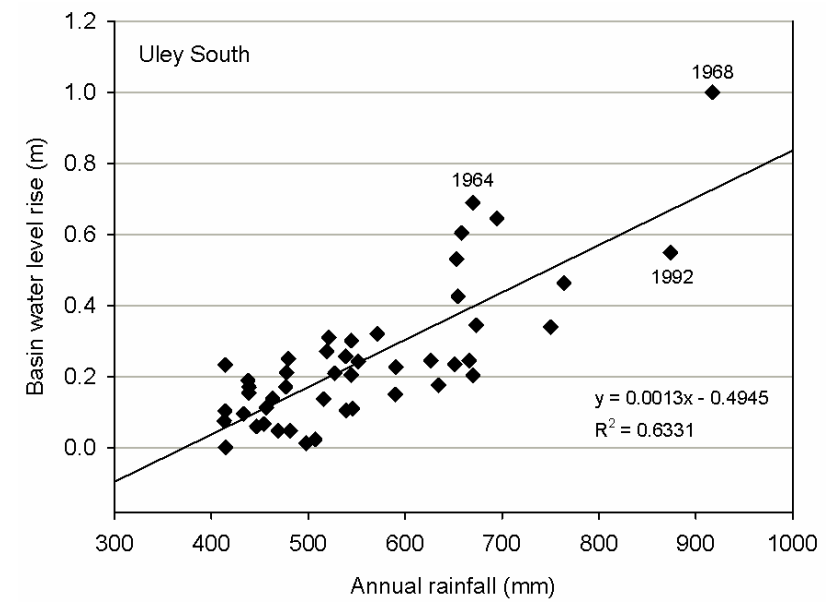

(a)

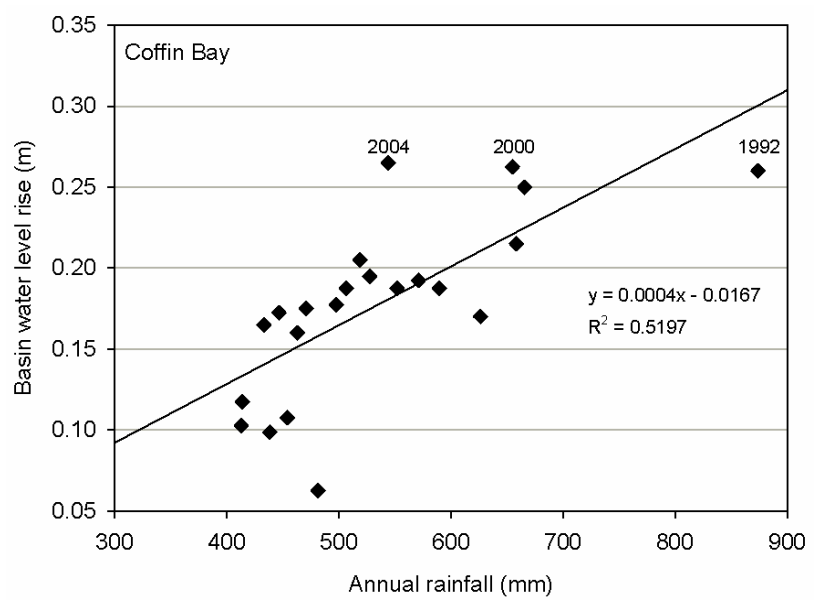

(b)

Two factors are considered to have caused this. Firstly, the Uley South basin has established a new equilibrium level, approximately $1 \mathrm{~m}$ lower due to groundwater pumping that began in 1976. Secondly, $156 \mathrm{~mm}$ of the 1992 rainfall occurred during summer months and the corresponding water level rise is not accounted for, as seasonal water level rise in the recharge period. However, in response to the 59\% increase in annual rainfall in 1992 from the annual average, a 150\% increase in water level rise was observed. In contrast, the observed increase in water level rise in Coffin Bay in 1992 is about 6\%. Thus, recharge in karst aquifers increases as the rainfall-runoff increases, the limiting factor being the amount of rainfall. At the lower end of annual rainfall $(380 \mathrm{~mm})$, Uley South basin water level rise is negligible (Figure 11), but such a lower end could not be confirmed for the Coffin Bay lens A.

Analysis by Evans [33] suggest a net rise in water level in Uley South requires at least $74 \%-80 \%$ of annual rainfall or at least 10 days of rain greater than $10 \mathrm{~mm}$ is required during the period of May to September.

Depending on the intensity of rainfall during the year, monthly monitoring of water level between April and October may not necessarily capture the peak water level. Whilst higher daily rainfall is not necessarily an indication of single large rain event, percentage of rainfall that fell between May to October to annual rainfall; together with percentages of rainfall greater than $10 \mathrm{~mm}(22 \%-63 \%)$ and 
$20 \mathrm{~mm}(0 \%-31 \%)$ of annual rainfall, recorded at Big Swamp station, given in Figure 12. This indicates $57 \%-90 \%$ of annual rain received in recharge period.

Figure 12. Characteristics of rainfall.

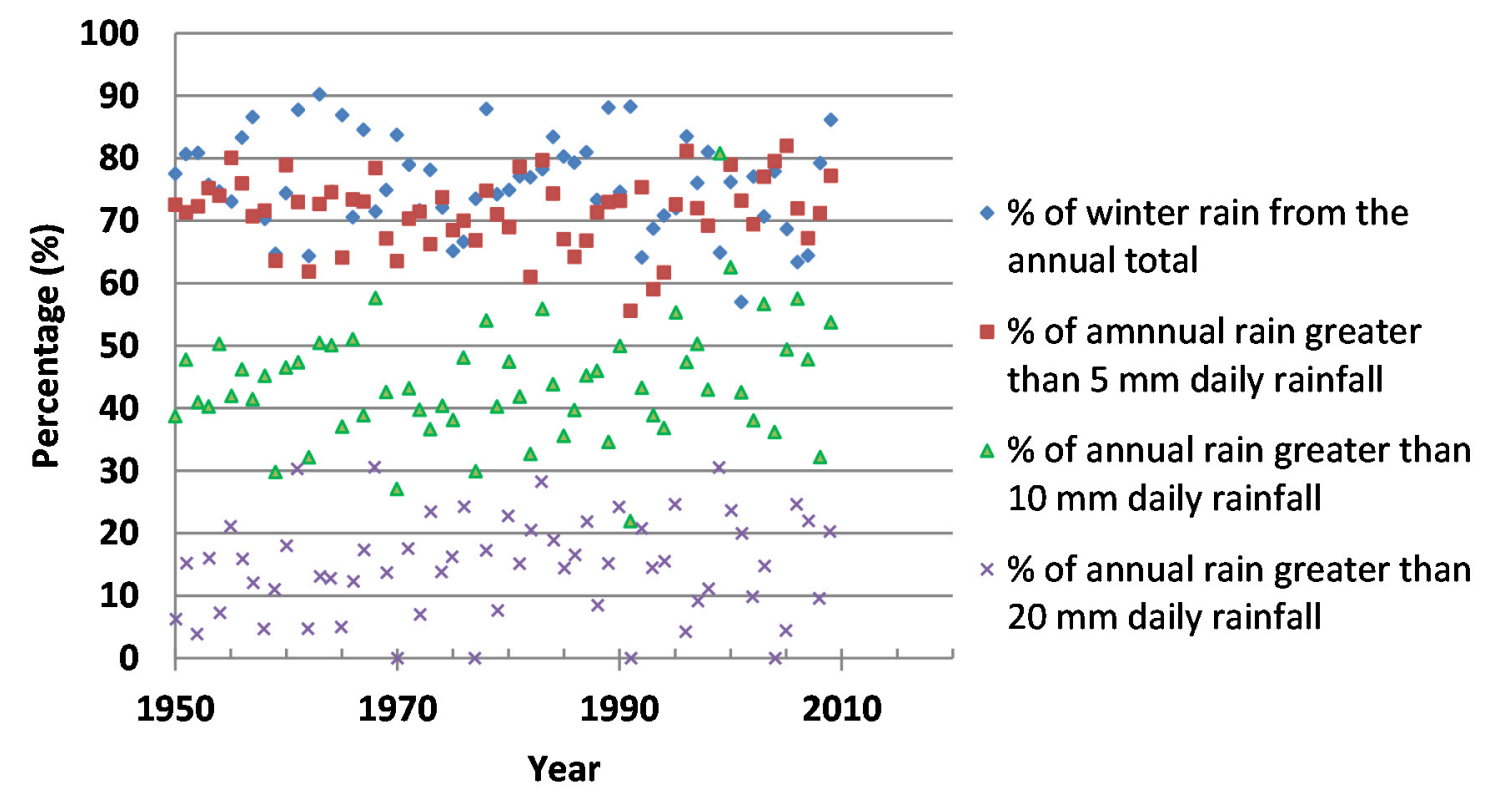

Regardless of percentage of rain fell during the recharge period, water level rise decrease rapidly during below average rainfall years (Table 1). For a given year, about $18 \%-44 \%$ of annual rainfall is comprised of daily rain less than $5 \mathrm{~mm}$, which may evaporate on heavily calretised surface horizons in Uley South basin and Robinson lens.

Evans [33] observe two types of water level rise in Uley South; an immediate (within hours) short lived, sharp rise after significant rainfall events, followed by a constant decay rate giving a "saw-toothed" shaped hydrograph (as evident in Robinson lens Figure 9a, inset); and a second type being a gradual rise with low magnitude, delayed up to days or weeks [33]. The first type of response indicates rapid recharge which would occur through solution features such as sinkholes [33] and the second type responses due to diffuse recharge processes.

\subsection{Groundwater Mixing Zones}

Understanding of the nature and extent of a groundwater mixing zone in a karstic system can help determine the relative importance of non-homogeneity in an aquifer system and its potential impact on the resource estimate. The results of chemical analyses of groundwater in the fresh water lens; from nested monitoring wells WRG 34 and WRG 35 located adjacent to Poocher Swamp, town water supply wells, and a monitoring wells located outside the fresh water lens (Figure 7); and the surface water samples taken from Tatiara Creek and Poocher Swamp are shown in the Piper diagram (Figure 13). 
Table 1. Basin average water level response in Uley South to below average annual rainfall.

\begin{tabular}{|c|c|c|c|c|c|}
\hline \multirow[t]{2}{*}{ Year } & $\begin{array}{l}\text { Annual } \\
\text { Rainfall }\end{array}$ & $\begin{array}{c}\text { Recharge Period Rain } \\
\text { to Annual Rainfall }\end{array}$ & $\begin{array}{c}\text { Annual rainfall } \\
>10 \text { mm of Daily Rain }\end{array}$ & $\begin{array}{c}\text { Annual Rainfall } \\
>20 \text { mm of Daily Rain }\end{array}$ & $\begin{array}{l}\text { Basin Average Water } \\
\text { Level Rise in Uley South }\end{array}$ \\
\hline & $(\mathbf{m m})$ & $(\%)$ & $(\%)$ & $(\%)$ & (m) \\
\hline 1961 & 476 & 88 & 47 & 30 & 0.17 \\
\hline 1962 & 438 & 64 & 32 & 5 & 0.12 \\
\hline 1965 & 437 & 64 & 32 & 5 & 0.19 \\
\hline 1967 & 414 & 85 & 39 & 17 & 0.23 \\
\hline 1969 & 477 & 75 & 43 & 14 & 0.21 \\
\hline 1970 & 469 & 84 & 27 & 0 & 0.05 \\
\hline 1972 & 479 & 72 & 40 & 7 & 0.25 \\
\hline 1977 & 414 & 74 & 30 & 0 & 0.0 \\
\hline 1982 & 456 & 77 & 33 & 20 & 0.11 \\
\hline 1987 & 446 & 81 & 45 & 22 & 0.06 \\
\hline 1988 & 497 & 73 & 46 & 8 & 0.01 \\
\hline 1991 & 414 & 88 & 22 & 0 & 0.1 \\
\hline 1994 & 413 & 71 & 37 & 15 & 0.08 \\
\hline 1997 & 481 & 76 & 50 & 9 & 0.05 \\
\hline 1998 & 433 & 81 & 43 & 11 & 0.1 \\
\hline 2002 & 463 & 77 & 38 & 10 & 0.14 \\
\hline 2006 & 438 & 63 & 58 & 25 & 0.16 \\
\hline 2008 & 471 & 79 & 32 & 10 & 0.16 \\
\hline
\end{tabular}

Figure 13. Piper diagram for fresh water lens.

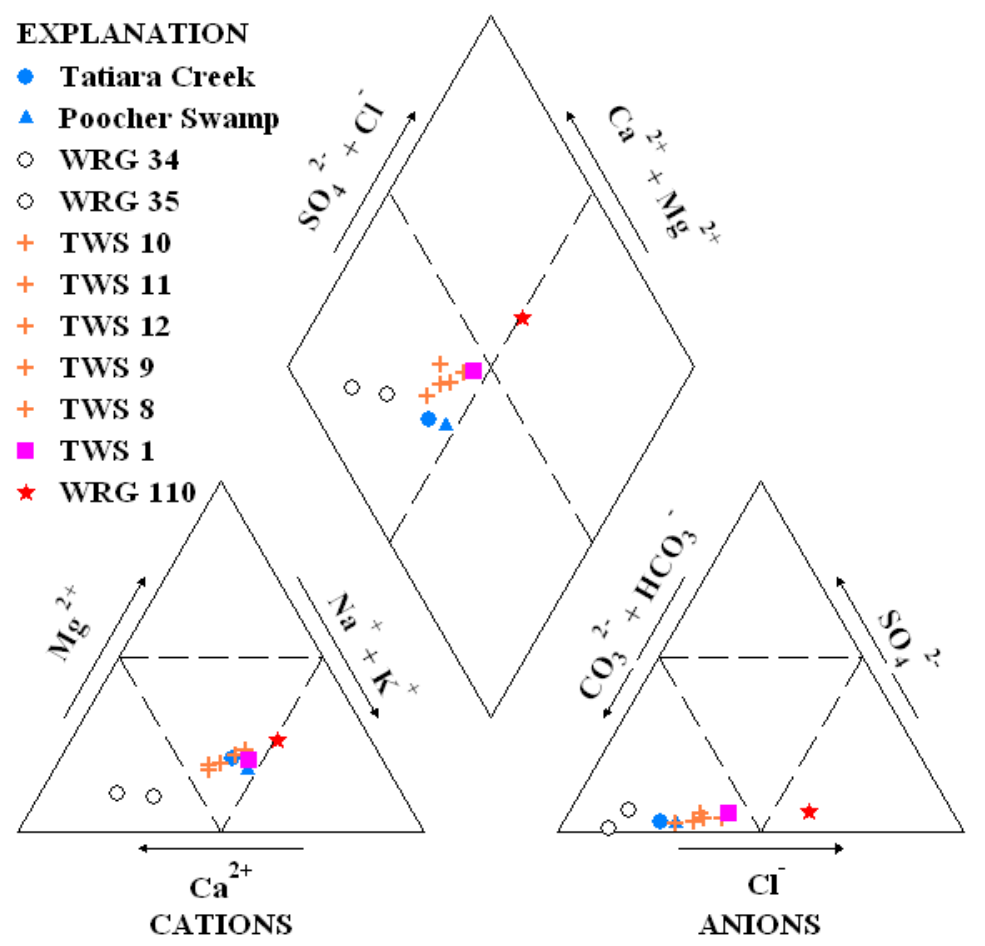

The major ion chemistry results show no dominant cations in Tatiara Creek, Poocher Swamp and town water supply (TWS) wells: TWS 10, TWS 8, TWS 9 and TWS 1. However, water chemistry changes from Tatiara Creek (Na-Ca-Mg- $\left.\mathrm{HCO}_{3}-\mathrm{Cl}\right)$ and Poocher Swamp $\left(\mathrm{Na}-\mathrm{Ca}-\mathrm{HCO}_{3}-\mathrm{Cl}\right)$ water types 
to calcium dominant water: $\mathrm{Ca}-\mathrm{HCO}_{3}$ and $\mathrm{Ca}-\mathrm{Na}-\mathrm{HCO}_{3}$, in WRG 34 and WRG 35 as a result of dissolution of calcite. Except for WRG 110 monitoring well which is chloride dominant, all anions are $\mathrm{HCO}_{3}$ dominant.

All town water supply well water types are either $\mathrm{Ca}-\mathrm{Na}-\mathrm{HCO}_{3}-\mathrm{Cl}$ (TWS 10, TWS 9, TWS 8) or $\mathrm{Na}-\mathrm{Ca}-\mathrm{HCO}_{3}-\mathrm{Cl}$ ((TWS 11, TWS 12, TWS 1) as a result of different degree of mixing along flow paths between two end member water types in the fresh water lens, which are: Ca-HCO3 in WRG 34 and $\mathrm{Na}-\mathrm{Mg}-\mathrm{Ca}-\mathrm{Cl}-\mathrm{HCO} 3$ in WRG 110.

This observation is consistent with gradual decrease in $\delta^{18} \mathrm{O}$ enrichment due to mixing, from Poocher Swamp (-0.34\%o VSMOW-Vienna Standard Mean Ocean Water) to $-3.05 \%$, $-3.08 \%$, $-3.23 \%$ VSMOW at TWS 10, TWS 8, and TWS 9 respectively. Within the fresh water lens, no other significant point recharge sources exist. This indicates that mixing occurs over the distance between point recharge source and ambient regional groundwater, making a non-homogeneous plume. Therefore, as the spatial distribution of chloride concentrations vary due to mixing, it is not possible to obtain representative groundwater chloride that represents either point or diffuse recharge within the plume that cross the watertable plane.

\subsection{Preferential Flow Paths}

In the Blue Lake capture zone, Mount Gambier, a large variation in measured electrical conductivity (EC) of sub-aquifer groundwater at point recharge locations and diffuse recharge areas is present [28]. The lowest salinity measured at the deepest aquifer sub-unit which is characterised by extensive fracturing [28,41]. Two low salinity (EC) zones (Figure 14a), indicated by low EC in the profile, are found in monitoring well BLA164 and BLA017 (Figure 5). The upper low EC zone is due to both diffuse and point recharge to the aquifer. The lower EC zone of BLA164 at 33-34.5 m depth (Figure 14a) is identified as the primary fracture pathway to Blue Lake [41]. According to Waterhouse [38], the presence of solution features, mainly dolines is common, and their concentration south-west of Mount Gambier probably indicates more intensive fracturing. Salinity profiles obtained from drainage wells (Figure 14b) located in the zone of the primary fracture pathway further south; down gradient to BLA164 confirm that low salinity water moves at greater depth, confirming the Waterhouse [38] and Lawson [41] observations. This indicates the existence of preferential groundwater flow pathways at different depths. A similar observation is made by Herczeg et al. [16] in their study on Poocher Swamp sinkholes. Three monitoring wells were used at $10 \mathrm{~m}, 50 \mathrm{~m}$ and $150 \mathrm{~m}$ down-gradient of the two sinkholes to study water level behaviour during recharge. The first two wells were completed shallow, $6 \mathrm{~m}$ below water level, and the third one (at $150 \mathrm{~m}$ ) was completed at $50 \mathrm{~m}$ depth and about $35 \mathrm{~m}$ below water level. Maximum water level rise had been observed at the well $150 \mathrm{~m}$ from the sinkholes indicating direct sub-surface connectivity to the sinkholes.

Overall, these results show the complex nature of tracking flow paths in karst, and the non-homogeneity at point recharge sources, aquifer monitoring wells, and along flow paths. As the conduit flow carries freshly recharged water from point sources, it may not be possible to obtain representative groundwater chloride as an input to the conventional CMB. 
Figure 14. Salinity profiles (a) Monitoring wells (b) Drainage wells.

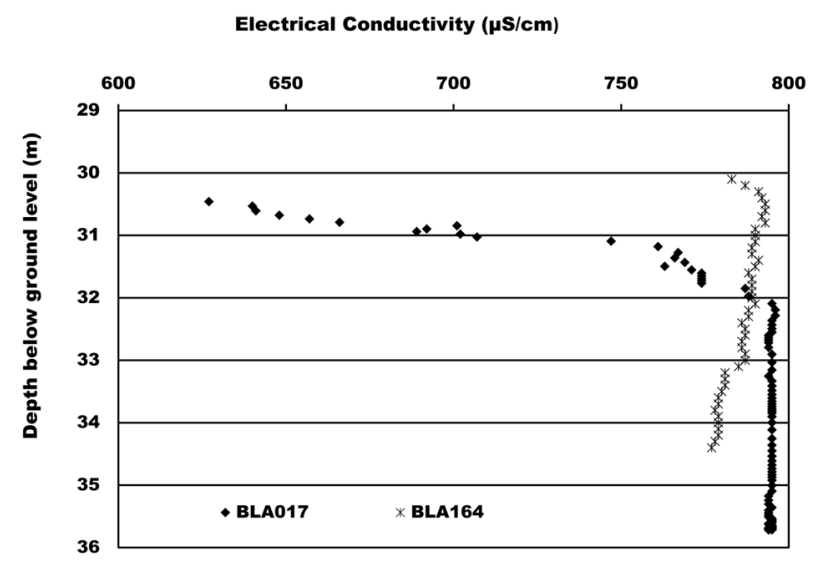

(a)

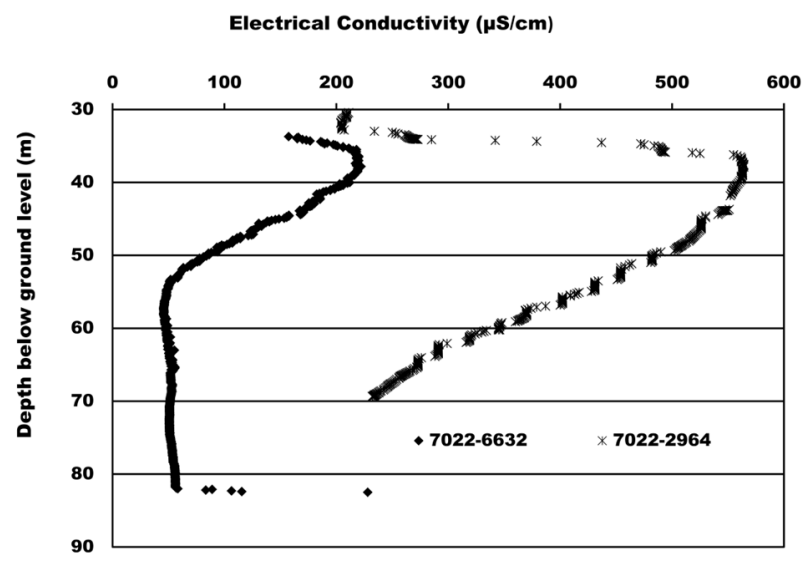

(b)

\subsection{Characteristics of Point Recharge-Chloride to $\delta^{18} \mathrm{O}$ Relation}

In their study of Uley South basin, Ordens et al. [35] used the chloride vs. $\delta^{18} \mathrm{O}$ relationship to determine relative contribution of point recharge to total recharge. These authors argued that the contribution to recharge by flow through sinkholes is only a small fraction of total recharge. This conclusion is based on a lack of intermediate data points between groundwater chloride and rain water chloride in the chloride $v s . \delta^{18} \mathrm{O}$ plot (Figure 15b) [35]. In Figure 15, chloride $v s . \delta^{18} \mathrm{O}$ plots are given for the Robinson lens, Uley South, Blue Lake capture zone at Mount Gambier and Poocher Swamp freshwater lens in the Tatiara catchment [36]. The widest gap between groundwater chloride and rain water chloride is about $250 \mathrm{mg} \cdot \mathrm{L}^{-1}$ in the Robinson lens where average annual rainfall is lowest, followed by $83 \mathrm{mg} \cdot \mathrm{L}^{-1}$ in the Uley South aquifer (Figure 15a,b). In the Blue Lake capture zone where average annual rainfall is $160 \mathrm{~mm}$ greater than Uley South, a gap of $43 \mathrm{mg} \cdot \mathrm{L}^{-1}$ exists, even with a high number of point recharge sites, principally through the 400 drainage wells directly recharging the aquifer [28]. Intermediate data points between rainfall and groundwater chloride can be obtained via chloride measurements taken at drainage wells, which are discrete recharge points (Figure 15c). In Poocher Swamp in the Tatiara catchment, the freshwater lens of 7 to $10 \mathrm{~km}$ length developed due to the high volume of annual creek flow recharging the limestone aquifer [29]. The fresh water plume intercepted by a number of measurement points shows that there are no gaps between surface water and groundwater chloride (Figure 15d) at the nearest measurement point.

Lack of intermediate data points [35] may result from monitoring bias. A number of factors influence this observation: aquifer water level monitoring wells not necessarily near sinkholes or located outside the small pockets of fresher inflow associated with sinkholes; difficulty in obtaining groundwater samples from sinkholes due to their complex architecture and the unknown extent of conduit in saturated zone; small catchments contributing to sinkholes not generating sufficient runoff volume to develop fresh water plumes to reach measurement points; fresh recharge water from point sources occupying a small cross sectional area compared to granular porosity areas and carried away by conduit flows; intermittent and transient nature of point recharge; and non-uniform mixing of granular porosity water with point recharge water. Therefore, a lack of intermediate data points between rainfall and most groundwater does not discount point recharge. 
Figure 15. Chloride $v s .{ }^{18} \mathrm{O}$ for point recharge dominant groundwater basins (a) Robinson lens (b) Uley South (c) Mount Gambier Blue Lake capture zone (d) Poocher Swamp fresh water lens.

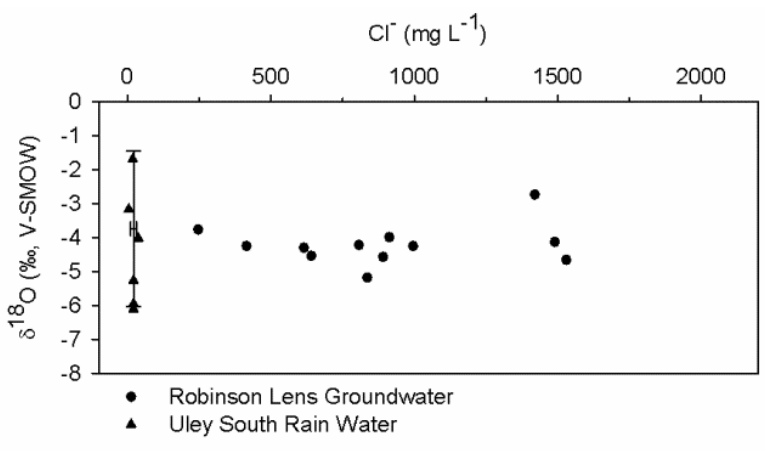

(a)

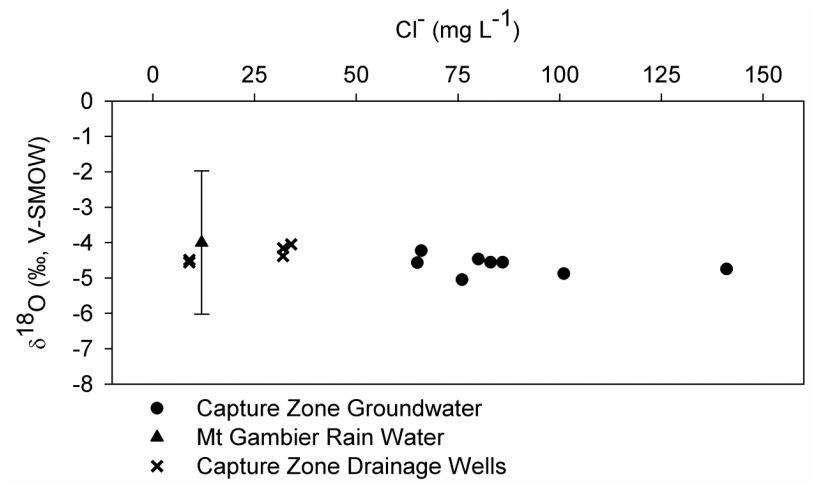

(c)

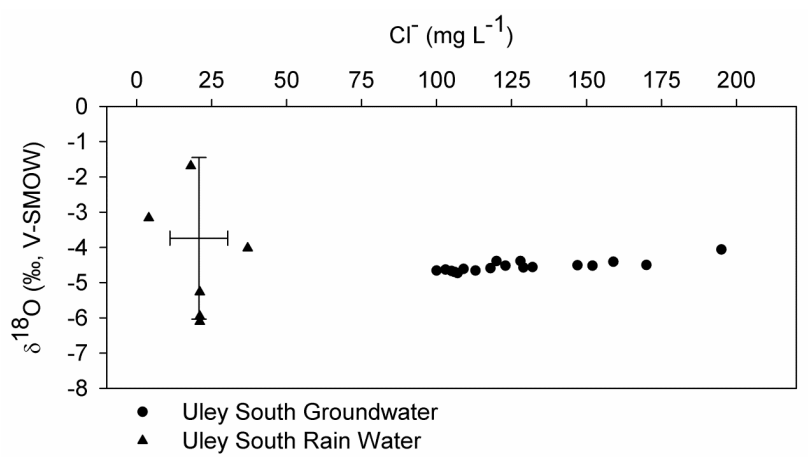

(b)

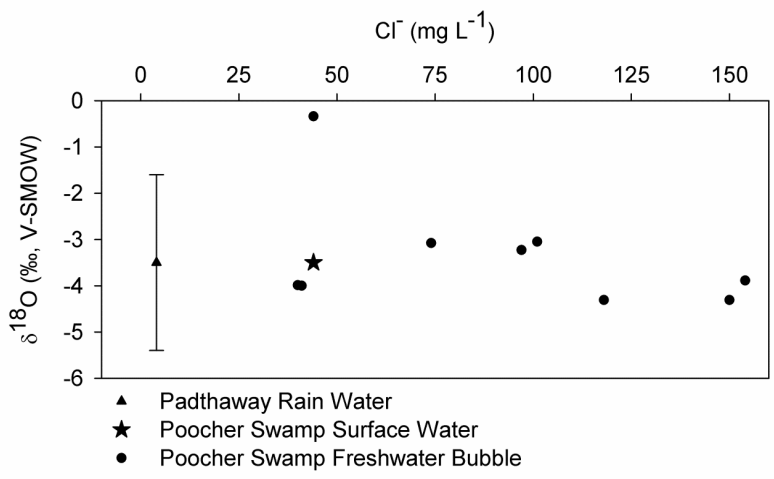

(d)

\subsection{Comparison of Conventional CMB Estimated Recharge with Recharge Estimation by Watertable} Fluctuation (WTF) Method, Groundwater Modelling and Point Recharge

The conventional CMB method is frequently used for recharge estimation and is given by [25-27]:

$$
R=\frac{P c_{p+D}}{c_{g}}
$$

where $\mathrm{R}\left(\mathrm{mm} /\right.$ year) is average annual recharge, $\mathrm{P}\left(\mathrm{mm} \cdot \mathrm{year}^{-1}\right)$ is average annual rainfall $(\mathrm{mm}), \mathrm{c}_{p+\mathrm{D}}$ $\left(\mathrm{mg} \cdot \mathrm{L}^{-1}\right)$ is representative mean chloride concentration of rain water including contributions from dry deposition [35] and $\mathrm{cg}_{\mathrm{g}}\left(\mathrm{mg} \cdot \mathrm{L}^{-1}\right)$ is chloride concentration in groundwater. In the absence of direct measurement, the $\mathrm{c}_{p+\mathrm{D}}$ can be estimated from Hutton [59] using:

$$
c_{p+D}=35.45 \times\left\{\frac{0.99}{d^{0.25}}-0.23\right\}
$$

where " $\mathrm{d}$ " is distance in $\mathrm{km}$ from the ocean in the prevailing wind direction. Thus, for Uley South at $6 \mathrm{~km}$ from coast to the centre of the basin gives $\mathrm{c}_{p+D}$ of $14.3 \mathrm{mg} \cdot \mathrm{L}^{-1}$; for Mount Gambier at $20 \mathrm{~km}$ from the coast, $\mathrm{c}_{p+\mathrm{D}}$ of $8.5 \mathrm{mg} \cdot \mathrm{L}^{-1}$ and for the Poocher Swamp at $100 \mathrm{~km}$ from the coast produce $\mathrm{c}_{p+\mathrm{D}}$ of $3 \mathrm{mg} \cdot \mathrm{L}^{-1}$.

For the four case studies described in this paper, the conventional CMB is applied in a manner similar to Ordens et al. [35] to estimate recharge. For application of conventional CMB to estimate 
total recharge, an average chloride concentration in the fresh water lens of $91 \mathrm{mg} \cdot \mathrm{L}^{-1}$ was used for the Poocher Swamp fresh water lens, while for Mount Gambier, $63 \mathrm{mg} \cdot \mathrm{L}^{-1}$ was used. For the estimation of diffuse recharge, average chloride concentration for diffuse recharge zones were taken from Figure $3 \mathrm{a}$ for Uley South $\left(149 \mathrm{mg} \cdot \mathrm{L}^{-1}\right)$, from Figure 5 for Mount Gambier $\left(63 \mathrm{mg} \cdot \mathrm{L}^{-1}\right)$, and from Figure 7 for Poocher Swamp $\left(712 \mathrm{mg} \cdot \mathrm{L}^{-1}\right)$.

Based on the annual flow of Tatiara Creek for the period 1980-2010, average annual recharge to groundwater in Poocher Swamp is taken as $2.5 \times 10^{6} \mathrm{~m}^{3}$ through the two sinkholes. A similar estimate of about $2.3 \times 10^{6} \mathrm{~m}^{3}$ was made by Stadter and Love [60] in 1987. As part of the recharge estimation for the Blue Lake in Mount Gambier [31], Nguyen [61] used the urban storm water model MUSIC [62] for quantifying storm water runoff to drainage wells. In the study, rainfall and runoff process was modelled for the period 2007-2012 using a daily time step with daily rainfall and evaporation data. For the average annual rainfall of $750 \mathrm{~mm}$, Nguyen [61] estimated $6.6 \times 10^{6} \mathrm{~m}^{3}$ of runoff volume, equivalent of $390 \mathrm{~mm}$ per year, flows through drainage wells to groundwater from a catchment area of $16.8 \mathrm{~km}^{2}$.

In Uley South basin, Ward et al. [63] used LEACHM [64], a variably saturated model of the soil profile that uses the curve number approach described by Williams [65] to estimate surface runoff to sinkholes. This resulted in a point recharge component alone that was greater than the estimated recharge using conventional CMB (Table 2). Since total recharge is a combination of both, point and diffuse recharge components, these results clearly indicate that the conventional CMB is underestimating actual total recharge when point recharge is a contributing factor. Application of conventional CMB to estimate recharge to the Poocher Swamp fresh water lens requires further consideration.

Table 2. Comparison of recharge estimates with point recharge.

\begin{tabular}{lcccc}
\hline \multicolumn{1}{c}{$\begin{array}{c}\text { Recharge } \\
\text { estimation method }\end{array}$} & \multicolumn{4}{c}{ Average annual recharge (mm per year) } \\
\cline { 2 - 5 } $\begin{array}{l}\text { Diffuse recharge from } \\
\text { the Conventional CMB }\end{array}$ & - & 52.7 & 101 & 1.8 \\
\hline Point recharge & - & $75[63]$ & $390[28,61]$ & $127[60]$ \\
\hline $\begin{array}{l}\text { Total recharge from the } \\
\text { Conventional CMB }\end{array}$ & $7.6[31]$ & $53-60[35]$ & 101 & 14 \\
\hline $\begin{array}{l}\text { Total recharge from } \\
\text { WTF method }\end{array}$ & $38[31]$ & $129[35]$ & - & - \\
\hline $\begin{array}{l}\text { Total recharge from } \\
\text { Groundwater models }\end{array}$ & $27[31]$ & $146[66]$ & - & - \\
\hline
\end{tabular}

Martin and Screaton [67] recognise that karst aquifer systems comprise of two components, in which a majority of the storage occurs within the matrix porosity of the diffuse system, while the majority of transport occurs in the small cross-sectional area of fractures and dissolution conduits. Thus, even if an extensive monitoring network is established, the tendency is to monitor long-term resident chloride concentration of matrix porosity as evident in Uley South basin and Mount Gambier Blue Lake capture zone. Therefore, the estimated diffuse recharge component and the total basin recharge using the conventional CMB are similar in magnitude, but significantly lower than recharge estimated using WTF method and by groundwater modelling. It is perceived that simplified assumptions in the conventional 
$\mathrm{CMB}$ and the inability to obtain representative chloride concentrations make direct application of the conventional $\mathrm{CMB}$ method to point recharge dominant groundwater basins questionable. Therefore, there is nothing to be gained by further improving data for application of the conventional CMB [31]. For recharge estimation in point recharge dominant basins, watertable fluctuation, numerical groundwater modelling, Darcy flow calculation or water budget methods are more suitable as these methods are independent of the particular mode of recharge [31].

Average chloride concentration in the Poocher Swamp fresh water lens of $91 \mathrm{mg} \cdot \mathrm{L}^{-1}$ or a recharge value of $14 \mathrm{~mm}$ per year are not representative of recharge to the lens. In fact vertical recharge $\left(1.8 \mathrm{~mm} \cdot\right.$ year $\left.^{-1}\right)$ that crosses the watertable plane corresponds to a diffuse zone groundwater chloride concentration of $712 \mathrm{mg} \cdot \mathrm{L}^{-1}$ outside the lens. The fresh water lens's recharge water is generated outside the plume area. Low salinity and chloride concentrations found in the fresh water lens results from a lateral flux moving from point source recharge down gradient. Taking chloride measurements from a lateral flux to estimate vertical recharge is essentially estimating "apparent recharge". This is because the estimated recharge never crossed the watertable plane at the location.

\section{Conclusions}

Understanding of recharge mechanisms and reliable recharge estimates are critical to evaluation and management of water resources. Reliability of estimated recharge depends largely on applicability of the particular method employed, availability of reliable data and adequate spatial coverage of data for the basin [31]. While knowledge of long-term average recharge rates is beneficial to groundwater managers, in karst aquifers recharge estimation using average annual rainfall can miss the high recharge yielded from above average rainfall. Many methods have been developed for estimating recharge at different spatial and temporal scales [4]. Methods such as watertable fluctuation or numerical modelling are independent of the mode of recharge processes; problems arise in maintaining the assumptions of the conventional CMB in karst aquifers. This is because the conventional CMB requires assumption of a steady-state chloride mass flux crossing the watertable plane [26,27] but point recharge is highly transient; further, application of the conventional CMB to karst aquifers uses long-term average rainfall as an input, but high levels of recharge occur due to above average rainfalls; and thirdly, there is difficulty in specifying representative long-term average chloride concentrations for groundwater due to the presence of conduit flow and occurrence at differing depths, along with different mixing zones of fresher water pockets or plumes around point recharge sources. In many cases, small fresher water pockets may also be transient. In this regard, Subayani and Sen [68] show that the conventional CMB is valid under less variable systems under steady-state conditions; otherwise the conventional CMB should be viewed as an over simplification. Thus in karst aquifers the reliability of the conventional CMB is questionable as the underpinning assumptions of the conventional CMB equation do not hold.

The paper presents case studies showing that karst systems have a distinct hydrologic function resulting from a duality of flow regimes in infiltration and recharge, and in preferential groundwater flow paths. This study contrasts the suggestion that the presence of a measured gap between groundwater and rainwater chloride in the chloride $v s . \delta^{18} \mathrm{O}$ plot, is indicative of sinkholes only indirectly recharging the aquifer. This is evident in a recent recharge response to an extreme rain event in the Robinson lens. Non-homogeneity exists at point recharge sources and along flow paths. Given that the extent of fresh 
water pockets at point recharge locations and along conduits may not be entirely known, it may not be possible to obtain representative salinity or chloride samples for groundwater systems when point recharge is a contributing factor.

\section{Acknowledgments}

The editor and two anonymous reviewers are thanked for their useful comments. Much help was received from the following, who are gratefully acknowledged: Keith Smettem and Jacqueline Frizenschaf for contribution to an earlier version of the manuscript and reviews, Glyn Ashman for review of the manuscript, Jeff Lawson for assistance with groundwater sampling in Mount Gambier, Ian Miller for providing photograph of the Robinson lens, Brooke Swaffer for assistance with figures.

\section{Conflicts of Interest}

The author declares no conflict of interest.

\section{References}

1. Simmers, I., Ed. Estimation of Natural Groundwater Recharge; Reidel: Boston, MA, USA, 1988.

2. Sharma, M.L., Ed. Groundwater Recharge; A.A. Balkema: Rotterdam, the Netherlands, 1989.

3. Healy, R.W.; Cook, P.G. Using groundwater levels to estimate recharge. Hydrogeol. J. 2002, 10, 91-109.

4. Scanlon, B.R.; Healy, R.W.; Cook, P.G. Choosing appropriate techniques for quantifying groundwater recharge. Hydrogeol. J. 2002, 10, 18-39.

5. Taylor, C.J.; Greene, E.A. Quantitative Approaches in Characterizing Karst Aquifers. In U.S. Geological Survey Karst Interest Group Proceedings; Water Resources Investigations Report 01-4011; Kuniansky, E.L., Ed.; U.S. Geological Survey: Reston, VA, USA, 2001; pp. 164-166.

6. Taylor, C.J.; Greene, E.A. Hydrogeologic characterization and methods used in the investigation of karst hydrology, Chapter 3: Field techniques for estimating water fluxes between surface water and groundwater. In Techniques and Methods 4-D2; Rosenberry, D.O., LaBaugh, J.W., Eds.; U.S. Department the Interior, U.S. Geological Survey: Reston, VA, USA, 2008.

7. Swaffer, B.A.; Holland, K.L.; Doody, T.M.; Li, C.; Hutson, J. Water use strategies of two co-occurring tree species in a semi-arid karst environment. Hydrol. Process. 2014, 28, 2003-2017.

8. Johnson, T.B.; McKay, L.D.; Layton, A.C.; Jones, S.W.; Johnson, G.C.; Cashdollar, J.L.; Dahling, D.R.; Villegas, L.F.; Fout, G.S.; Williams, D.E.; et al. Viruses and bacteria in karst and fractured rock aquifers in East Tennessee, USA. Ground Water 2011, 49, 98-110.

9. Schwinning, S. The water relations of two evergreen tree species in a karst savanna. Oecologia 2008, 158, 373-383.

10. Estrada-Medina, H.; Graham, R.; Allen, M.; Tuttle, W.; Jimenez-Osornio, J.J. Importance of subsurface soil pockets for plant growth in a karst environment. In Proceedings of the 19th World Congress of Soil Science, Soil Solutions for a Changing World, Brisbane, Australia, 1-6 August 2010. 
11. Meyerhoff, S.B.; Karaoulis, M.; Fiebig, F.; Maxwell, R.M.; Revil, A.; Martin, J.B.; Graham, W.D. Visualization of conduit-matrix conductivity differences in a karst aquifer using time-lapse electrical resistivity. Geophys. Res. Lett. 2012, 39, doi:10.1029/2012GL053933.

12. Ford, D.C.; Williams, P. Karst Hydrogeology and Geomorphology; John Wiley: Chichester, UK, 2007.

13. Hartmann, A.; Weiler, M.; Wagner, T.; Lange, J.; Kralik, M.; Humer, F.; Mizyed, N.; Rimmer, A.; Barbera, J.A.; Andreo, B.; et al. Process-based karst modelling to relate hydrodynamic and hydrochemical characteristics to system properties. Hydrol. Earth Syst. Sci. 2013, 17, 3305-3321.

14. Gunn, J. Point-recharge of limestone aquifers-a model from New Zealand karst. J. Hydrol. 1983, 61, 19-29.

15. Leaney, F.W.; Herczeg, A.L. Regional recharge to a karst aquifer estimated from chemical and isotopic composition of diffuse and localized recharge, South Australia. J. Hydrol. 1995, 164, 363-387.

16. Herczeg, A.L.; Leaney, F.W.J.; Stadter, M.F.; Allan, G.L.; Fifeld, L.K. Chemical and isotope indicators of point source recharge to karst aquifers, South Australia. J. Hydrol. 1997, 192, 271-299.

17. Lerch, R.N.; Wicks, C.M.; Moss, P.L. Hydrologic characterization of two karst recharge areas in Boone County, Missouri. J. Cave Karst Stud. 2005, 67, 158-173.

18. White, W.B. Conceptual Model for Karstic Aquifers. Speleogenesis and Evolution of Karst Aquifers. Available online: http://speleogenesis.info/journal/publication.php?id=4491 (accessed on 15 January 2013).

19. Hallberg, G.R.; Hoyer, B.E. Sinkholes, Hydrogeology and Groundwater Quality in Nort-East Iowa; Open File report 82-3; Iowa Department of Natural Resources, Geological Survey Bureau: Des Moines, IA, USA, 1982.

20. Tihansky, A.B. Sinkholes, West-central Florida. In Land Subsidence in the United States; U.S. Geological Survey Circular 1182; U.S. Geological Survey: Reston, VA, USA, 1999; pp. 121-140.

21. Gordon, D.W. Hydrologic factors affecting sinkhole development in a field in the Karst Dougherty Plain, Southwest of Albany, Georgia. U.S. Geological Survey, Georgia Water Science Center. In Proceedings of the Georgia Water Science Conference, Athens, GA, USA, 11-13 April 2011.

22. Hyland, S.E.; Kennedy, L.M.; Younos, T.; Parson, S. Analysis of Sinkhole Susceptibility and Karst Distribution in the Northern Shenandoah Valley, Virginia: Implications for Low Impact Development Site Suitability Models; VWRRC Special Report SR31-2006; Virginia Water Resources Research Center: Blacksburg, VA, USA, 2006.

23. Bakalowicz, M. Karst Groundwater: A challenge for new resources. Hydrogeol. J. 2005, 13, 148-160.

24. Schwartz, B.E.; Schreiber, M.E. Qunantifying potential recharge in mantled sinkholes using ERT. Ground Water 2009, 47, 370-381.

25. Gee, G.W.; Zhang, Z.F.; Tyler, S.W.; Albright, W.H.; Singleton, M.J. Chloride Mass Balance: Cautious in Predicting Increased Recharge Rates; Soil Science Society of America: Madison, WI, USA, 2005; pp. 72-78.

26. Allison, G.B.; Hughes, M.W. The use of environmental chloride and tritium to estimate total recharge to an unconfined aquifer. Aust. J. Soil Res. 1978, 16, 181-195. 
27. Wood, W.W. Use and misuse of the chloride mass balance method in estimating groundwater recharge. Technical Commentary. Groundwater 1999, 37, 2-3.

28. Somaratne, N.; Lawson, J.; Ashman, G.; Nguyen, K. Recharge to Blue Lake and strategies for water security planning, Mount Gambier, South Australia. J. Water Resour. Prot. 2014, 6, 772-783.

29. Somaratne, N. Mapping Poocher Swamp Fresh Water Lens; South Australian Water Corporation: Adelaide, South Australia, Australia, 2011.

30. Somaratne, N.; Frizenschaf, J. Geological control upon groundwater flow and major ion chemistry with influence on basin management in a coastal aquifer, South Australia. J. Water Resour. Prot. 2013, 5, 1170-1177.

31. Somaratne, N.; Smettem, K.; Frizenschaf, J. Three criteria reliability analyses for groundwater recharge estimations. Environ. Earth Sci. 2014, 72, 2141-2151.

32. Brown, K.G.; Harrington, G.A. The Dynamic Behaviour of a Stressed, Semi-Arid Groundwater Basin, South Australia; Report DWLBC 2003/08; Department of Water, Land and Biodiversity Conservation: Adelaide, SA, Australia, 2002.

33. Evans, S.L. Estimating Long-Term Recharge to Thin, Unconfined Carbonate Aquifers Using Conventional and Environmental Isotopes Techniques: Eyre Peninsula, South Australia. Master's Thesis, Flinders University of South Australia, Adelaide, South Australia, Australia, 1997.

34. Harrinngton, N.; Zulfic, D.; Wohling, D. Uley Basin Groundwater Modelling Project, vol. 1, Project Overview and Conceptual Model Development; DWLBC Report 2006/01; Government of South Australia: Adelaide, Australia, 2006.

35. Ordens, C.M.; Werner, A.D.; Post, V.E.A.; Hutson, J.L.; Simmons, C.T.; Irvine, B.M. Groundwater recharge to a sedimentary aquifer in the topographically closed Uley South Basin, South Australia. Hydrogeol. J. 2012, 20, 61-72.

36. Somaratne, N. Hydrogeology of the Uley South Basin; SA Water 013/1; South Australian Water Corporation: Adelaide, South Australia, Australia, 2013.

37. Allison, G.B.; Harvey, P.D. Freshwater Lakes, In Natural History of the South Australia; Tyler, M.J., Twidale, C.R.T., Ling, J.K., Holmes, J.W., Eds.; Royal Society of South Australia: North Terrace, SA, Australia, 1983; pp. 61-74.

38. Waterhouse, J.D. The Hydrogeology of the Mount Gambier Area; Report of Investigations 48; Geological Survey of South Australia: Adelaide, SA, Australia, 1977; pp. 1-61.

39. Turner, J.V.; Allison, G.B.; Holmes, J.W. Environmental isotope methods for the determination of lake-groundwater relations: Applications to determine the effect of man's activities. In Proceedings of the International Conference on Groundwater and Man, Sydney, Australia, 5-9 December, 1983; Volume 1.

40. Environment Protection Authority (EPA). Guidelines for Stormwater Management in Mount Gambier; EPA: Carlton, Australia, 2007.

41. Lawson, J.S. Water Quality and Movement of the Unconfined and Confined Aquifers in the Capture Zone of the Blue Lake, Mount Gambier, South Australia and Implications for Management. Master's Thesis, The University of South Australia, Adelaide, Australia, 25 March 2013.

42. Drexel, J.F.; Preiss, W.V. The Geology of South Australia: The Phanerozoic; Mines and Energy, South Australia, Geological Survey of South Australia: Adelaide, Australia, 1995; Volume 2. 
43. Love, A.J. Groundwater Flow Systems: Past and Present, Gambier Embayment, Otway Basin, South-East Australia. Ph.D. Thesis, Flinders University of South Australia, Adelaide, Australia, October 1991.

44. Li, Q.; McGowran, B.; White, M.R. Sequences and biofacies packages in the Mid-Cenozoic Gambier Limestone, South Australia: Reappraisal of foraminiferal evidence. Aust. J. Earth Sci. 2000, 47, 955-970.

45. MacKenzie, G. Hydrochemical Data of the Tatiara Catchment; Department of Environment, Water and Natural Resources: Naracoorte, Australia, 2013.

46. Vail, J. Groundwater Sampling; SESDRPROC-301-R3; U.S. Environmental Protection Agency, Science and Ecosystem Support Division: Athens, GA, USA, 2011.

47. Water Quality Sampling-Guidance on the Design of Sampling Programs, Sampling Techniques and the Preservation and Handling of Samples; AS/NZS 5667.5; Australia/New Zealand Standard: Homebush, Australia, 1998.

48. APHA/AWWA/WEF Method 3120B. In Standard Methods for the Examination of Water and Wastewater, 20th ed.; American Public Health Association, Washington, DC, USA, 1999.

49. APHA/AWWA/WEF Method 4500. In Standard Methods for the Examination of Water and Wastewater, 22nd ed.; American Public Health Association, Washington, DC, USA, 2012.

50. APHA/AWWA/WEF Method 2320. In Standard Methods for the Examination of Water and Wastewater, 22nd ed.; American Public Health Association, Washington, DC, USA, 2012.

51. Epstein, S.; Mayeda, T.K. Variation of the ${ }^{18} \mathrm{O} /{ }^{16} \mathrm{O}$ ratio in natural waters. Geochim. Cosmochim. Acta 1953, 4, 213.

52. PDZ Europa Ltd. 20-20 ANCA-GSL User Manual V.4.0; PDZ Europa Ltd.: Sandbach, UK, February 2001.

53. YSI Incorporated. Environmental Monitoring Systems Operations Manual. Available online: http://wenku.baidu.com/view/d785b92058fb770bf78a55ca.html (accessed on 03 September 2014).

54. Abdalla, O.A.E. Groundwater recharge/discharge in semi-arid regions interpreted from isotope and chloride concentrations in north White Nile Rift, Sudan. Hydrogeol. J. 2009, 17, 679-692.

55. Van der Akker, J. The Use of Stable Isotopes and Chloride to Assess Evaporation and Transpiration Impacts from Flood Irrigation. Master's Thesis, School of Environment, Flinders University, Adelaide, South Australia, Australia, 2010.

56. Custodio, E. Hydrogeochemistry and traces. In Groundwater Problems in Coastal Areas (Studies and Reports in Hydrology); Custodio, E., Brugeman, G.A., Eds.; United Nations Educational, Scientific and Cultural Organization: Paris, France, 1987; pp. 213-269.

57. Keese, K.E.; Scanlon, B.R.; Reedy, R.C. Assessing controls on diffuse groundwater recharge using unsaturated flow modelling. Water Resour. Res. 2005, 41, doi:10.1029/2004/WR003841.

58. Lee, L.J.E.; Lawrence, D.S.L.; Price, M. Analysis of water level response to rainfall and implications for recharge pathways in the Chalk aquifer, SE England. J. Hydrol. 2006, 330, 604-620.

59. Hutton, J.T. Chloride in rainwater in relation to distance from the ocean. Search 1976, 7, 207-208.

60. Stadter, F.; Love, A.J. Tatiara Proclaimed Region Groundwater Assessment; South Australian Department of Mines and Energy, Report Book 87/87; Government of South Australia: Adelaide, Australia, 1987. 
61. Nguyen, K. Estimating the Annual Stormwater Yield in the Blue Lake Capture Zone, South Australia. Master's Thesis (unpublished), University of South Australia, Adelaide, Australia, 2013.

62. Model for Urban Stormwater Improvement (MUSIC); MUSIC Development Team, e Water CRC: Canberra, Australia, 2009. Available online: http://www.ewater.com.au (accessed on 17 September 2014).

63. Ward, J.D.; Hutson, J.; Howe, B.; Fildes, S.; Werner, A.D.; Ewenz, C. A Modelling Framework for the Assessment of Recharge Processes and Climate Change: Eyre Peninsula; Report developed through the Eyre Peninsula Groundwater Allocation Planning Project; Eyre Peninsula Natural Resource Management Board, Government of South Australia: Adelaide, Australia, 2009.

64. Hutson, J.L. LEACHM-A Process Based Model of Water and Solute Movement, Transformations, Plant Uptake and Chemical Reactions in the Unsaturated Zone, Version 4; Research Series No. R03-1; Department of Crop and Soil Sciences, Cornell University: Ithaca, NY, USA, 2003.

65. Williams, J.R. Chapter 18-Runoff and Water Erosion. In Modelling Plant and Soil Systems; Agronomy Monograph 31; Hanks, J., Ritchie, J.T., Eds.; American Society of Agronomy: Madison, WI, USA, 1991.

66. Werner, A.D. A Groundwater Model of Uley South Basin, South Australia; Flinders University of South Australia: Adelaide, South Australia, Australia, 2010.

67. Martin, J.M.; Screaton, E.J. Monitoring Well Response to Karst Conduit Head Fluctuations: Implications for Fluid Exchange and Matrix Transmissivity in the Floridan Aquifer; Geological Society of America Special paper 404; Department of Geological Sciences, University of Florida: Gainesville, FL, USA, 2006; pp. 209-217.

68. Subayani, A.; Sen, Z. Refined chloride mass balance method and its application in Saudi Arabia. Hydrol. Process. 2006, 20, 4373-4380.

(C) 2014 by the authors; licensee MDPI, Basel, Switzerland. This article is an open access article distributed under the terms and conditions of the Creative Commons Attribution license (http://creativecommons.org/licenses/by/3.0/ 